\title{
Circulating tumor cells: a broad perspective
}

Victor Akpe ${ }^{* 1,2}$, Tak H. Kim ${ }^{1,2}$, Christopher L.Brown ${ }^{1,2}$, lan E. Cock ${ }^{* 1,2}$

\section{Affiliations}

1 School of Environment and Science, Griffith University, Nathan Campus, QLD 4111, Australia.

2 Environmental Futures Research Institute, Griffith University, Nathan Campus, QLD 4111, Australia.

\section{Authors' ORCID:}

VA, (0000-0001-8639-321X); THK, (0000-00024495-176X); CLB, (0000-0001-5135-0244);

IEC, (0000-0002-8732-8513)

* Corresponding Author

Email:1.Cock@griffith.edu.au

Conflict-of-interest: All authors declare no conflict of interest 


\section{Table of Contents}

Circulating tumor cells: a broad perspective Error! Bookmark not defined.

Abstract

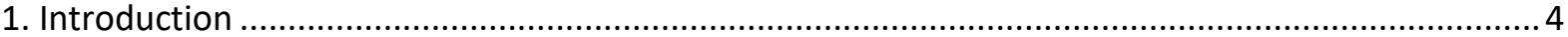

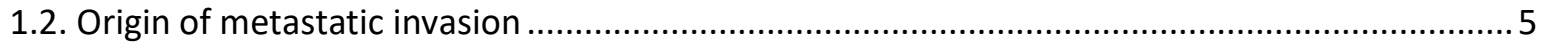

1.3. Challenges associated with CTCs based technologies ...............................................

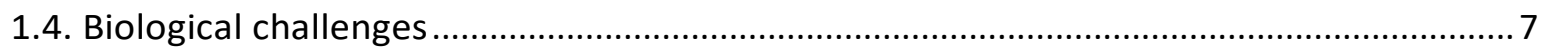

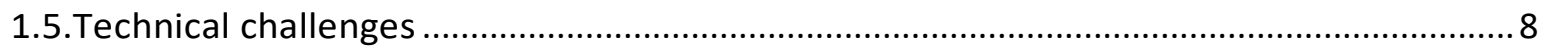

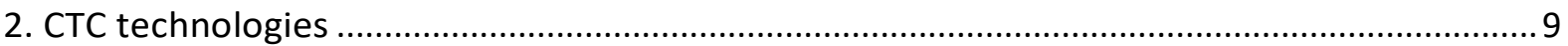

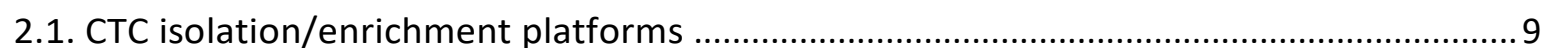

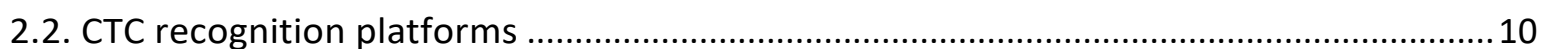

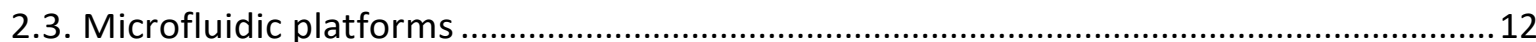

2.4. Techniques based on electrochemistry, surface plasmon resonance (SPR) and surface enhanced Raman scattering (SERS) ...................................................................... 17

2.5. Nanoparticle-based electrochemical/SPR/SERS technologies for CTC application ........18

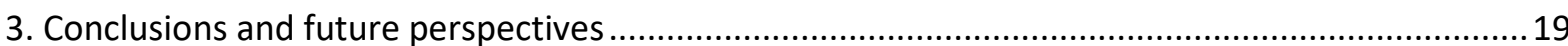

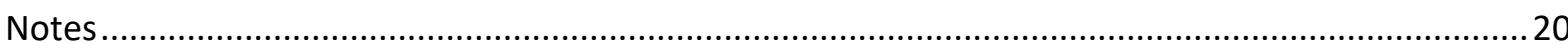

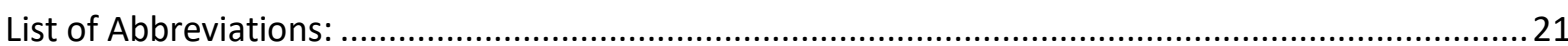

Figures and captions: ............................................................. Error! Bookmark not defined.

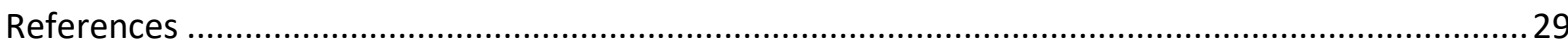




\section{Abstract}

Circulating tumor cells (CTCS) have recently been identified as valuable biomarkers for diagnostic and prognostic evaluations, as well for monitoring therapeutic responses to treatments. CTCs are rare cells which may be present as one CTC surrounded by approximately 1 million white blood cells and 1 billion red blood cells per milliliter of peripheral blood. Despite the various challenges in CTC detection, considerable progress in detection methods have been documented in recent times, particularly for methodologies incorporating nanomaterial-based platforms and/or integrated microfluidics. Herein, we summarize the importance of CTCs as biological markers for tumor detection, highlight their mechanism of cellular invasion and discuss the various challenges associated with CTC research, including vulnerability, heterogeneity, phenotypicity and size differences. In addition, we describe nanomaterial agents used for electrochemistry and surface plasmon resonance applications, which have recently been used to selectively capture cancer cells and amplify signals for CTC detection. The intrinsic properties of nanomaterials have also recently been exploited to achieve photothermal destruction of cancer cells. This review describes recent advancements and future perspectives in the CTC field.

Keywords: 


\section{Introduction}

Circulating tumor cells (CTCS) constitute an exceedingly small fraction of cells relative to a background of 1 million white blood cells and 1 billion red blood cells per millimeter of peripheral blood [1]. CTCs and circulating tumor microemboli (CTM) are the intermediate stages in metastasis [2, 3]. The goal of cancer invasion is territorial dominance and eventual cell death[4]. The key cellular process involves (i) intravasation (ii) CTCs extratravasation process to bone marrow or other organs where the cells are disseminated and metastasised at the local site (ii) CTM may also undergo intravascular proliferation to bone marrow or other organs before the tumor cells are disseminated and metastasised at the local site [3]. The spontaneity of these processes and the identification of CTCS/CTM and leukocytes in the blood have been a subject of considerable interest over the years. Therefore, understanding the role of CTC in a diseased cancer patient is paramount for long term survival. Furthermore, approaches toward CTC capture and detection, cell type enumeration and the subsequent application of relevant therapeutic measures are essential for the management of cancer patients.

Despite the extremely low concentration of CTCs in body fluids, they can potentially provide information regarding diagnosis, prognosis, and follow-up of therapeutic responses to treatments [5]. CTCs are therefore considered valuable biomarkers in targeted molecular therapies for cancer patients and are also candidates for determining CTC phenotypes in preclinical models[5-7]. The extremely low concentration of CTCs in peripheral blood samples makes isolation, enumeration, and detection daunting. Moreover, due to a purification step that is required for their characterisation, captured CTCs may become damaged during the isolation process.

However, CTCs are challenging to accurately enumerate and detect even by the current standard method, CellSearch ${ }^{\circ}$, which remains the only test technology approved by the Food and Drug Administration (FDA) [1]. As illustrated in Figure 1, the CellSearch method preselects based on EpCAM expression [8]. Additionally, there are still no clear guidelines for optimal CTC enumeration for clinical decision-making in treating primary and metastatic breast cancers [9]. Furthermore, CellSearch is based on the enrichment of CTCS using the epithelial based adhesion molecule (EpCAM) or negative depletion of leukocytes $[1,10]$. Although this technology has recently been used to demonstrate the clinical relevance of CTCS as an independent and predictive marker for early breast cancer [11], prognostic evaluation remains widely conjectural for many reported clinical cases including: (i) nonmetastatic colorectal cancer patients [12] and (ii) tumor cell recurrence in patients with localized prostate cancer [13]. However, in small cell lung cancer (SCLC) and non-small-cell lung cancer (NSCLC) patients, CellSearch (Veridex) remains the validated approach for the prognostic evaluation of CTCs [14-16]. For instance, CTCs are highly detectable in patients with stage IV NSCLC [14] and SCLS [15]. 
Therefore, the CellSearch technology must be reviewed carefully on a case by case basis. Importantly, CellSearch can only detect CTCs that express EpCAM (EpCAM+CTC) and not EpCAM with low or no CTC (EpCAM ${ }^{-}$CTC). Therefore, when Wit et al. combined platforms, they were able to capture (EpCAM-CTC) using a filtration and fluorescent staining protocol and EpCAM+CTC was captured with CellSearch technology. Thus, their combined platforms increased CTC detection in the blood samples of 27 metastatic lung cancer patients to $41 \%$ as opposed to $15 \%$ detected by CellSearch only, which is indicative of a good outcome in the study [10, 17]. However, CTC with EpCAM- affinity has not been confirmed from large pool studies and molecular characterisation of this marker from EpCAM ${ }^{+}$remain undifferentiated. The Lei Xu et.al [18] study compared CellSearch to their optimised Parsortix systemexample of an epitope independent method. The group recovered a significantly more $\mathrm{CK}^{+} \mathrm{CTC}$ than the CellSearch method as well as capture CTC clusters from $7.5 \mathrm{ml}$ of 10 prostate cancer patient samples. In another study, Arutha Kulasinghe et. al.[19] compared CellSearch with two epitopeindependent approaches in advanced stage head and neck cancer (HNC) patients. The results obtained for single CTCs isolation with different technologies included: (18.6\%) CellSearch, (46.4\%) ScreenCell ${ }^{\circledR}$, and (64\%) by RosetteSep ${ }^{\mathrm{TM}}$ including detection of CTC clusters. The role of EpCAM negative CTCs is not fully understood - whether they are prognostic has not been investigated [20].

In this review, we emphasize nanomaterial-based assays for nanoscale sensing by electrochemical methods and surface plasmon techniques. Other in-depth areas covered include a molecular understanding of the mode of action of cancer invasion in tumor biology and CTC characterization. We also discuss some critical challenges facing existing technologies. In addition, we emphasize the importance of surface plasmon resonance (SPR) and surface-enhanced Raman scattering (SERS) as complementary tools for biolectrochemical detection processes. Finally, we cover the potential of nanotheranostics to provide future outpatient precision therapeutics for cancer.

\subsection{Origin of metastatic invasion}

Due to the complexity of metastasis, the molecular nature of cancer is not fully understood. However, in the classical seed-and-soil hypothesis established by Stephen Paget in 1889 [21], cancer is described as the cross-talk between selected cancer cells (the seed) and specific organ environment (the soil). It has been extensively reviewed by Fidler et al. [22-32]. 1. Paget's hypothesis states that carcinomas are biologically heterogeneous, containing subpopulations of cells having different regulatory pathways and invasive attributes, and undergoing metastatic processes. 2. Metastasis occurs through the passage of CTCS through regulatory pathways, including adaptation of invasion features such as CTCS covered with platelets (embolization); CTC survival in circulation; arrest in distant capillary beds; and extravasation into, and multiplication within, the organ parenchyma (functional organ site only). 3 . Metastasis depends on multiple interactions (cross-talk) within metastatic cells that may eventually 
be controlled by tumor cells. 4. Intravasation mechanism may be further divided into single CTCs and CTM. The single CTCs may undergo extratravasation process via bone marrow or other organs where the cells are disseminated and metastasised at the local site. Another regulatory pathway is that CTM may be developed via intravascular proliferation to bone marrow or other organs before the tumor cells are disseminated and metastasised at the local site [3]. The inherent morphological attributes of CTCs include [33] : (i) they are more rare than CTC clusters (ii) these clusters are formed by oligoclonal tumor cell groupings, whose origin may be related to biclonal gammopathies - where two or more distinct proteins are synthesised [34] (iii) CTC clusters have 23-50X higher metastatic potential to single CTCs. Additionally, the importance of circulating clusters has recently been highlighted by Nicola Aceto group in breast cancer and human glioblastoma models [35, 36]. Plakoglobin presence has been identified as the probable cause of CTC cluster formation in breast cancer cell but the relationship of these two variants in patients remains evaluated [33]. Further readings on CTC clusters has been covered by Qi Zhang group [37].

The most recent updates on the seed-and-soil hypothesis reviewed by Akhtar et al.[21] and Massagué et al. [38], described the invasion journey, summarised in Figure 2. The tumor cells that break away from the primary tumor lose their epithelial properties and acquire mesenchymal-like properties during the intravasation stage [39]. The epithelial-mesenchymal transition [39] is mediated by cadherin molecule switching (calcium-dependent cell adhesion), involving the downregulation of $\mathrm{E}$-cadherin and upregulation of $\mathrm{N}$-cadherin. The modulation of cadherin and $\mathrm{N}$-cadherin levels are indicative of metastatic breast cancer $[4,40]$. Furthermore, during EMT, upregulation of vimentin, integrin- $\alpha v \beta 6$ and metalloproteinase also occurs. Upregulation of $\mathrm{N}$-cadherin is indicative of invasive metastatic breast cancer types $[41,42]$. In metastasis, integrin- $\alpha \vee \beta 6$ binds several ligands from the extracellular matrix, thus maintaining upregulation activity and increasing migration survival and inactivation of apoptosis. Integrin- $\alpha \vee \beta 6$ is usually overexpressed in breast cancer metastatic lesions during the regulation process, and it plays a key role in tumor growth, invasion, early angiogenesis activity and metastasis $[43,44]$. Mesenchymal cells then undergo structural changes that enable the invasion of the surrounding extracellular matrix, stroma, and platelets. CTCs interaction with platelets, helps to provide protection against destructive physical forces from the surrounding environment through the activation of thrombosis and fibrin deposition. This step is known as the embolization stage. Because of the various immune defensive systems and the mechanical stresses of blood flow, only the few CTCs that escape the primary tumor invade the surrounding host tissues or organs. The invading cells at this stage are known as disseminated tumor cells (DTCs), which is the transition from mesenchymal to epithelial cells. Less than $0.01 \%$ of CTCs survive to the next stage of tumor latency [45]. Finally, after the extravasation stage, DTCs settle into a dormancy lasting for several weeks to 
several decades; these cells may eventually undergo micrometastasis and produce metastatic lesions. Some characteristics of cancer cells and major areas of clinical research advancement are highlighted in Table 1.

\subsection{Challenges associated with CTCs based technologies}

The challenges associated with CTCs have been highlighted in numerous review articles [4648], which include pathways to the development of new technologies that are able to separate damaged cells from the viable CTCs count, affording accurate prognostic evaluations. Another area most recently reviewed is the mode of CTC release after capture to enable culture expansion of CTC phenotypes, highlighted by the Kelly group [49] as one of the key areas for development of next generation materials in this area. There is also a paradigm shift from a 2dimensional (2D) tissue-culture model to 3-or 4-dimesional (3D or 4D) microenvironments for subsequent CTC expansion [50,51]. Interestingly, the advent of imprintable materials sensitive to environmental changes such as solvents, heat, mechanical stress, or other external stimuli may pave may for a more-advanced shape than $3 D$, which is a shape-shift environment in a 4D system. With a 4D imprintable material, it will be possible for materials to exist in two stable forms (exhibiting zero degree at each stage of the freedom) in response to environmental changes such as solvents, heat, mechanical stress, or other external stimuli that effect change. More importantly, these microenvironments enable dynamic, spatio-temporal cellular behaviors to be modulated under physiological conditions and provide a utility model for drug screening [52-54].

\subsection{Biological challenges}

The current challenges hindering the efficient use of CTCs in biological environments include CTC vulnerability and viability, and the inability to analyze viable CTCs through intracellular staining. Additionally, using the current FDA-approved standard, CellSearch ${ }^{\circ}$, CTCs may remain undetected because of a lack of detectable biological markers for recognizing other important non-EpCAM markers. Thirdly, CTCs have phenotypic heterogeneity, making enumeration difficult after isolation. CTCs also have a mixture of phenotypes, among which only cells positively expressing the antigen EpCAM are counted using CellSearch ${ }^{\circ}$, thus ignoring EpCAM CTC. Furthermore, captured CTCS may also be damaged during release, hindering downstream characterization. A recent review by Green et al. [49] highlights the mechanism of CTC release, which may occur via chemical, enzymatic, self-assembly-based and mechanosensitive modes or via a thermal release mechanism (Figure 3). Pertinent here is that next generation materials that can effectively capture and release CTCs have recently emerged and these materials 
enable culturing and expansion of CTCs, post capture, and provide an excellent platform for understanding CTC subpopulations and heterogeneity [46-49].

\subsection{Technical challenges}

The capability of any device to enrich CTCs present at typically 1-100 cells $/ \mathrm{ml}$ of whole blood is considered a significant performance evaluation matrix [55-57]. However, the performance of CTC multifarious approaches may affect data quality, specifically around capture efficiency evaluations, CTC heterogeneity, size variability, non-specific cellular labeling initiated during capture, analysis of unaccounted CTCs, misidentification of damaged CTCs to include them into the overall population figures, and finally limitations regarding blood sample volume and assay robustness in CTC capture $[58,59]$. Therefore, statistical considerations for any CTC device should be elucidated. For example, in one study [59], a cell-based assay calculation for flow cytometry of blood volume for high precision system was determined using equation 1 :

$$
r=\left(\frac{\mathbf{1 0 0}}{\mathbf{C V}}\right)^{2}, \quad \text { Equation } 1
$$

where $r$ represents the number of events that meet the required criterion. $\mathrm{CV}$ is the coefficient variation of a known positive control. From equation 1, if the desired CV is $10 \%, 100$ events are required, and the true value would be between $80-120$ events, which the authors state is close to the limit of detection for most laboratory cytometry tests. The same estimated value of the CV $\square 0 \%$ has been described as the cut-off value for improving the accuracy of the assay [58]. The statistical risk in this probability sampling is in setting a threshold cut-off for the number of CTCs captured as a direct way to evaluate a cancer patient's prognoses as either good or bad.

Another consideration that may have unwanted statistical and technical consequences is CTC damage caused by high flow-induced shear [60]. In one study, the microfluidic environment was modulated to generate a broad range of hemodynamic shear stresses [60]. Briefly, high shear stress causes CTC stress, thus inducing necrosis (unregulated cell death), preventing CTC attachment and inducing $90 \%$ necrosis within the first 4 hours of circulation and apoptosis within 16-24 hours. Additionally, it was observed that high shear stresses are effective at killing other types of epithelial based cancer cells as well as and drug-resistant breast cancer cells.

Phenotypic heterogeneity of CTCS is also a challenge (due to the complexities of the statistical analysis). Some researchers have used sophisticated algorithms, including the naive Bayesian classifier which is based on a probabilistic generative mixture model [61], to identify individual cells in a sample. Although complex statistical procedures are involved, the model is based on (i) identifying images to be processed and implementing an algorithm, (ii) subdividing 
the images processed, and (iii) re-identifying and grouping the images. The advantage with this platform is that the Bayes theorem is used to describe the probability of the event during processing of the images captured. The software package then evaluates the processed results with a degree of accuracy and precision, including true positives/negatives and false positives/negatives, this method of identifying phenotypic variables is one of the best ways of providing accuracy and its precision is close to $100 \%$. The clinical utility of this tool is that it can be used to perform automated screening for the existence of CTCs in patient samples and to support clinicians performing personalized medicine evaluation.

Finally, overcoming several other challenges in contemporary CTC research would result in system possessing (i) decreased assay preparation times, (ii) development of ultrasensitive biorecognition and isolation CTC platforms leading to (iii) the assembly of integrated microfluidic devices possessing ( $v$ ) diagnostic modalities suitable for both single cell and clustered cell characterization. For more details on current CTCs challenges, readers are directed to the following references $[1,46]$.

\section{CTC technologies}

Emerging platforms with nanomaterial interfaces are showing greater utility in electrochemical and optical sensing than traditional bulk materials. As most next generation methods are derived from well-established nanotechnology approaches, modern microfluidic devices are increasingly becoming more reliable in their application as CTC isolation/enrichment and CTC recognition platforms [49, 62-64]. For example, previous studies have reported nanowire detection for prostate cancer (reported limit of detection (LOD): 1 CTC/10 mL blood) [65] and the use of surface enhanced Raman Scattering (SERS), for head and neck cancer detection (LOD: 5 CTCs/mL) [66]. In this review, we highlight CTC methodologies under the broadest of classifications -Tables 2 and 3 provide a comprehensive summary of the different various CTC platforms along with their clinical relevance.

\subsection{CTC isolation/enrichment platforms}

CTC technologies in this category include physical separation and microfluidic-based platforms which have been extensively reviewed recently [57, 64, 67-72]. The methodologies are based on CTC differentiation from normal hematopoietic cells based on physical characteristics including size, density, electric charges, deformability, buoyant density and the dielectrophoretic mobility of cells in varying macro/microenvironments. Microfiltration devices are the most common in this group. Recently, a thermal nanoimprint method using polyethylglycol (PEG) has been applied to develop a microfiltration CTC trapping device in 
which blood is filtered through pores of defined sizes, thereby enabling cells larger than the pore size to be trapped. This type of device facilitates rapid isolation of CTCs without the need for labeling. The developed method achieved an average capture efficiency of $84 \%$ for lung cancer cells spiked into blood samples [73]. Although this method is attractive, the isolated CTCs are mostly impure or of mixed origin owing to the heterogeneity of cancer cells. Therefore, most technologies in this category are encumbered by size-selection issues. Additionally, detachment of CTCs from surfaces result in damaged and clustered CTCs cells arising from hemodynamic stress. A list of devices available on the market have been described in a recent review article [74] including Ficoll OncoQuick ${ }^{\mathrm{TM}}$ [75], CellSieve ${ }^{\mathrm{TM}}$ (Rockville, MD, USA)[76], ISET (Paris, France) [77], Cluster Chip [78], Parsotrix ${ }^{\text {TM }}$ (Angle PLC, Guildford, UK) [36], Resettable Cell Trap [74], Flexible Micro Spring Array (FMSA) [79] and ScreenCell (Sarcelles, France) systems.

Among CTC enrichment-based technologies, the Ficoll OncoQuick ${ }^{\mathrm{TM}}$ system is dependent on density gradient centrifugation and is based on positive selection. However, the Ficoll OncoQuick ${ }^{\mathrm{TM}}$ system is known to result in a substantial CTC loss $[7,75]$. Dielectrophoretic fieldflow fractionation (DEP) isolation approaches are also enrichment-based methods. They can be used to differentiate blood cells by differences in their dielectrophoretic properties. The technology can process millions of live cells in 30 minutes, with a high recovery rate. In practice, the platform combines the functions of DEP, as well as uses sedimentation and hydrodynamic lift forces to impose differential forces along the flow of cell types in the mixture. The platform has been used effectively in antigen-independent isolation of CTCs from blood [80-83].

\subsection{CTC recognition platforms}

CTC recognition platforms are based on the affinity of the specific antibodies used for quantifying the characteristics of biological processes toward antigens on targets (biomarkers). The measurable outcome may not necessarily correlate with a patient's experience but may be considered as a surrogate endpoint if there is consistency, and a clinical outcome is accurately predicted [84]. Therefore, biomarkers are considered both provisional and surrogate endpoints in clinical settings [84]. EpCAM is the most frequently used cell surface marker for the positive enrichment of CTCs, whereas cytokeratins (CKs) are targeted for postenrichment specific to CTCs. This immunological procedure has been used in a range of techniques, including the only FDA-approved platform, CellSearch ${ }^{\circ}$. EpCAM is a type I glycosylated membrane protein (30-40 kDa) that is overexpressed in most solid carcinomas but has low expression in healthy human epithelial tissues [85]. It has also been detected in 
benign colon disease [86]. However, EMT in cancer cells may lead to downregulation of both EpCAM and CKs, thus resulting in the exclusion of CTCs with a mesenchymal phenotype, which express high levels of mesenchymal markers $[14,87]$. As an alternative to $\mathrm{N}$-cadherin, other antigen-expressing phenotype variables have been found to increase the biorecognition performance of the CTC platform when a cocktail of antibodies for various epithelial and mesenchymal markers is used [14]. The negative depletion of blood cells is also a promising alternative to marker-based positive selection for CTCS that has been widely used with antibodies against CD45 to capture and deplete leukocytes [88].

The biorecognition platforms in this section consist of both functional and nanomaterialbased assays (See Table 3). Functional assays specifically target proteins expressed by tumor cells. Examples include collagen adhesion matrix assays (CAM) and epithelial ImmunoSpot assay (EPISPOT). Whereas the CAM assay involves cell digestion, EPISPOT assays remove leukocyte antigens via CD45 depletion; the above-mentioned two methods have high specificity and selectivity. Additionally, EPISOT assays have inherent purity issues $[67,89]$. Other examples of EpCAM-based recognition technologies apart from the FDA-approved CellSearch $^{\circ}$ have also been reported. These EpCAM-based technologies include MagSweeper [90], which provides high purity cells that may be further used in Western blot assays; GILUPI CellCollector, which is mostly used in in vivo collection of very large sample volumes [91], and CTC-iChip [92], in which target cell sizes are positively/negatively enriched by using an antibody-dependent cell capture method. Herringbone Chip [93] and CTC chip (also known as microposts array, Figure 4F) [94] are based on the principle of microvortices, which involve the passive mixing of blood samples to significantly increase interactions between target CTCs with an anti-EpCAM-coated chip. Anti-EpCAM can be replaced with another antibody for negative enrichment. The Adna Test [95]is used mainly for molecular profiling of HER2 and EpCAM. IsoFlux, which is also a microfluidic platform, uses flow control and immunomagnetic capture to enhance CTC isolation and immunofluorescence detection for counting individual CTCs [96].

Nanomaterial-based assays are increasingly used in the diagnostics field [97-100]. These materials have a robust structure, small size (nanometer) and controllable pore sizes. They also have a high surface-to-volume ratio and are chemically tailorable to specific dimensions. Moreover, assay-based magnetic nanoparticles have been used directly to capture cancer cells from a working buffer solution or spiked cancer cells in phlebotomy samples. In a most recent study, nanozyme containing iron oxide loaded with gold particles was used for cancer cell capture, cancer profiling of different markers, and in post capture expansion in vitro study[101]. The nanozyme platform showed a fast response time within a linear dynamic 
range, $10-10^{5}$ cellsml $^{-1}$ for investigated breast carcinoma of T47D breast cancer cell line, $>80 \%$ capture from $10^{2}$ to $10^{5} \mathrm{cellsml}^{-1}$, and LOD was calculated at $0.4 \mathrm{Uml}^{-1}$, with limit of quantification, $4 \mathrm{UmL}^{-1}$ in sterile PBS buffer solution. The advantage of magnetic nanomaterials is that captured CTCS can be purified after capture with an external magnet to decrease nonspecific adsorption or noise before they are transferred to the detection platform. Thus, nanomaterial-based biorecognition technologies have been used to provide probes for cancer biomarker detection [98], isolation of CTCs from whole blood, fluorescence imaging and photothermal destruction of tumor cells $[97,99,100]$.

\subsection{Microfluidic platforms}

Microfluidic platforms are miniaturized devices capable of isolating rare tumor cells with tailored microfilters of varying sizes, that consider flexibility, size, control, geometry, and density with precision [92-94]. These platforms are used for analyzing blood samples within a short time, with a high recovery rate and high throughput. They can function as a microcentrifugation device and can also be integrated with other nanotechnologies. The surface chemistry of these platforms allows to design further functionalities for the controllable release of cells. Microfluidic platforms have also been used in situ for the sequential analysis of isolated CTCs [93-96, 102-106]. Microfluidics have been tailored as micromixers [107] to create chaotic advection at a low Reynolds number $\left(300 \mu \mathrm{ms}^{-1}\right)$ or induce electrokinetic flow within a channel, the latter being used for translocating cells in low-cost microfluidic cytometry for tumor cell detection and enumeration [108]. A microfluidic isolation/enrichment platform that features state-of-the-art technology is a multifaceted, integral platform with multi-orifice flow fractionation and a dielectrophoretic (DEP) cell separation device for continuous flow separation of cancer cells from blood samples [109, 110].

Another example in this group is the microfluidic label-free approach, which presumably circumvents biomarker heterogeneity related to CTC loss. The device also provides an unbiased CTC enrichment, despite the average size overlap between physical properties of CTCs and other blood cells that might be present. Recent studies have reported that smaller CTC sizes below the pores size of the membrane filter $(8-11 \mu \mathrm{m})$ are cut-off, thus accounting for the majority of CTC loss during isolation [104].

Although microfluidic platforms present a variety of ways for capturing CTC at the singlecell level, the quantification and classification of CTCs remains challenging in modern biology for sorting of cells. One of the most advanced microfluidic cell sorting technologies is an 
automated, high throughput enrichment CTC identification/enumeration system known as eDAR (ensemble-decision aliquot ranking) [111-113]. The principle of the eDAR workflow is automatic sorting by size differentiation of CTCs within an aliquot ensemble. After the CTCS are sorted into various sizes, they are transferred to a microfluidic platform for further purification. The device is all-encompassing in that the workflow involves four enterable automated loops for (i) aliquot ranking, (ii) aliquot sorting and (iii) on-chip purification. Subsequent steps within the loop may involve labeling with secondary antibodies for downstream assays before image analysis. The microfluidic device is therefore considered useful for single cell analysis and detection. The working principle for microfluidic systems reviewed here is explained in the following sections and depicted in Figure 4.

Microcavity arrays for CTC entrapment which has a section of the microfluidic device integrated with a size-selective platform for rapidly isolating CTCs from other cell types (hematologic cells) in whole blood, on the basis of size differences and cell deformability are illustrated in Figure 4A. The recovered CTC cells on a microcavity array are amenable to downstream fluorescence profiling of immunophenotypic cells through scanning automated fluorescence. This device can efficiently trap single cells, including stem cells and progenitor cells. The attractive feature of this device is the customizable geometry which can be optimized to provide precisely controlled separation based on cellular size differentiation from whole blood. In addition, entrapment of CTCs does not require the expression of epithelial markers to analyze the number of trapped cells. Instead, the numbers are determined primarily by scanning and counting the specified area under an automated fluorescence microscope.

The spiral biochip depicted in Figure $4 \mathrm{~B}$ is an enrichment, label-free microfluidic CTC device that allows size-based separation of viable CTCs by using hydrodynamic forces present in curvilinear microchannels [114, 115]. The curvilinear channel is governed by Poiseuille flow conditions within the curved microchannel wall, where concentration rearrangements of particles occur. Particles of variable (or fractionable) sizes tend to equilibrate at the microchannel cross-section located at the different spiral bends, where they are acted on by inertial lift and Dean drag forces. The exertion of inertial lift force leads to particle migration from the channel center while the particles within the curvilinear channel experience centrifugal acceleration and are directed radially outward, thus forming two counter-rotating vortices known as Dean vortices and also known as secondary flow $[116,117]$. The magnitude of this flow is quantified by a dimensionless Dean Number (De):

$$
\mathrm{De}=\frac{\rho U_{f} D_{h}}{\mu} \sqrt{\frac{D_{h}}{2 R}}=\operatorname{Re} \sqrt{\frac{D_{h}}{2 R}} \quad \text { Equation } 2
$$


where $\rho$ is the density of the fluid medium $\left(\mathrm{kg} \mathrm{m}^{-3}\right), U_{f}$ is the average fluid velocity $\left(\mathrm{m} \mathrm{s}^{-1}\right), D_{\mathrm{h}}$ is the diameter of the channel $(\mathrm{m}), \mu$ is the fluid viscosity $\left.\left(\mathrm{Kg} \mathrm{m}^{-1} \mathrm{~s}^{-1}\right)\right), \mathrm{R}$ is the radius of curvature $(m)$ of the channel, and Re is the flow Reynolds number. Equation (2) is relevant for fluid flow within a curved channel when the inertial force is significant. Therefore, faster moving fluid near the walls re-circulates inward to create two counter-rotating vortices perpendicular to the primary flow direction [117]. These counter-rotating vortices, that give rise to secondary flow in microfluidic systems, have been used in fluid mixing on the basis of the concept of chaotic advection to create diffusive mixing in three-dimensional twisted channels and spiral curved channels. These systems (or vortices) result in efficient mixing and significant improvement over planar serpentine channels providing advantages for system [117-119].

Other label-free microfluidic CTC devices that allow size-based separation of viable CTCs are the straight microchannels described from the Papautsky lab $[116,120]$.The latest device from the lab is the straight microfluidic chip using a multi-flow channel [121]. A straight microchannel device is based on the working principle of inertial focusing that allows migrating cells to primarily flow through the microchannels until encumbered by sidewalls within the microchannel creating a shear-induced lift force. Consequently, cells gently migrate to equilibrium centered positions relative to the sidewalls under the influence of the rotationinduced lift force. Equilibration of particles positioning within a flow is managed by (1) shearinduced lift force (2) wall-induced lift force (3) rotation-induced lift force [122]. Migrating larger cells are closer to the channel centerline than smaller cells in a rectangular-cross section microchannel within an observation window frame [123]. However, in the multi-flow channel device developed from Papautsky lab, the lateral migration of cells mainly depends on the size of the cells. This process allowed CTCs to be separated from white blood cells (WBCs) without the use of affinity-based approaches. Also, with the latest device, Papautsky lab achieved (i) (> $87 \%$ ) purity separation of CTCs from WBCs without labeling (ii) $93 \%$ recovery rate at clinically relevant concentration of spiked cancer cells (iii) device also detected 6 CTCs from NSCLC patients (iv) non recovered for 5 healthy control subjects. With this latest device, the authors identified a potential application in CTCS/CTM separation, which may be extended to the separation of other cancer cell types.

Another platform with a particle trapping mechanism is the vortex chip (Figure 4C). This technology is based on two working principles: (i) inertial focusing and high-throughput particle alignment, and (ii) laminar microvortices and a particle trapping method. The first 
principle uses the alignment of randomly dispersed particle flow through a channel in a manner dependent on the $R e$ value. If $\operatorname{Re} \geq 1$, two counteracting inertial lift forces are immediately in place: a shear-gradient lift force, $F_{\mathrm{LS}}$, which directs particles toward the channel walls, and the concomitant wall effect lift force, $F_{\mathrm{LW}}$, which repels the particles toward the channel center line, which by default branches to two to four dynamic equilibrium positions located between the channel center line and the wall. The second part of this technology is the expansion of Figure $4 C$ that represents the entrance into the reservoir [124]. In principle, the reservoir makes use of multiple expansion-contraction for predictable laminar vortices known as Moffatt corner eddy flow [125], in which the flow near the corner between plane boundaries and a rigid wall at rest is determined by a certain critical angle. When the critical angle is lower than the angles between the planes, a series of eddy flows arise, decreasing in size and intensity. The practical application of this principle to cells of varying sizes within the reservoir is that larger cells are pushed away from the channel center through a separatrix - a boundary that divides two modes of distinct flow behavior into vortices - and remain stably trapped.

Another entrapping device known as a cluster chip is shown in Figure 4D. The device, by design, captures cluster cells that flows through the triangular pillars, streaming cells under a dynamic force balance at the cell-cell junctions to support a stable equilibrium [78]. The design is based on the juxtaposition of rigid triangular planes in arrays, such that the triangular vertices are in proximity, with an opening of approximately $12 \mu \mathrm{m} \times 100 \mu \mathrm{m}$. Under a low shear stress of blood flowing through the channel, only CTC clusters are captured, and single cells pass through. This device allows not only the capture of CTC clusters without tumor-specific markers from unprocessed blood but also integrity of cells captured are preserved. The Cluster chip device is also one of the few CTC platforms that exploits the geometry of aggregate cells to differentiate them from single cells in blood. Additionally, the device allows the downstream applications of CTC culture expansion.

A tailored filtration device in which the sample is placed on a Teflon membrane surface, with strong ring magnets (not shown in the diagram) for magnet-assisted sealing and a waste outlet is shown in Figure 4E. Parylene C is ( a substitution of Teflon membrane) used for cell filtration, which has a micropore membrane that can be arrayed with different pore diameters $(8-12 \mu \mathrm{m})$, is easily handled with tweezers. The mechanical strength of the membrane, high porosity and high reliability in liquid biopsy handling have been reported [126]. The high porosity of the membrane has been attributed to the edge-to-edge face of the micropore, increasing the high recovery rate of viable cells. Simultaneously, non-specific adhesion arising 
from background cells is decreased [127]. The micropore array platform design achieves a higher CTC recovery rate of $80-96 \%$, compared with similar filtration structures [127]. In addition to the use of this platform for CTC separation, the device has found broad applications in separating large volumes of exfoliated tumor cells from other body fluids such as bronchoalveolar lavage fluid, $(40-80 \mathrm{ml})$, urine $(500-1000 \mathrm{ml})$ and pleural fluid $(500-1000 \mathrm{ml})$, and has also been used to obtain more comprehensive information about ex vivo tumor sites; consequently, it is expected to be beneficial in precision medicine in the future $[126,127]$.

The Lim group [128] has recently developed a new platform called Microfluidic Centrifugal Nanoparticles Separation and Extraction ( $\mu$ CENSE, Figure $4 G$ ). The device has been used for rapid, label-free isolation of extracellular vesicles, EVs [129]. EVs play a vital role in intercellular communication among membrane cells, lipids, and RNA [130], and are regarded as important biomarkers. The $\mu$ CENSE technology is based on the principle of centrifugal microhydrodynamics [131] for separating particles according to their size differences. Pressurized fluidized particles driven along the serpentine separation channel are pushed away by radial particles toward the center of rotation based on size-selection. The centrifugal force that generates spin for the rotor assembly is actuated by a stream of air rushing into the inlet, which is set to operate at a given duration. The microfluidic chip is then removed and observed under a fluorescence microscope. Downstream analysis can be monitored by extraction of microparticles under vacuum. The platform potentially demonstrates EV extraction on a tabletop centrifuge within approximately 8 minutes, with $85 \%$ purity. The device is considered clinically relevant in point-of-care diagnostics because it does not require the use of a syringe pump and other accessories that might require a professional handler.

ClearCell FX system Biolidics Limited (formerly, Clearbridge BioMedics) has recently developed a simple microfluidic chip use for downstream analysis. While this invention is relatively new and is patent, it has a wide application for diagnostic, personalised treatment, and prognostic evaluation. It has been shown to be compatible with a label-free inertial microfluidics device for CTC enrichment in this study [132] for the examination of 30 patients with head and neck cancer, esophageal cancer, gastric cancer, colorectal cancer in the first phase; including advanced colorectal cancer in the second phase examination.

Another device using a liquid biopsy method is the lab-on-a-disc, Exo-Hexa table-top system (Figure 4H). The lack of efficient method for androgen-receptor splice variant 7(AR-V7) CTC test associated with castration-resistant prostate cancer (CRPC) remains a challenge in clinical practice. Extracellular vesicles (EVs) are secreted in most bodily fluids and holds promise as a non-invasive method. Particularly AR-V7 has been identified in advanced stage prostate cancer 
patients [133]. A recent discovery highlights the use of a urine-based liquid biopsy device for prostate cancer detection [134]. The working principle of the Exo-hexa disc device which is a modification of the previous Exo-disc [135], is that it has three chambers. The first chamber is used for sample loading, second chamber for filtration and third chamber as a waste storage, positioned in a radial outward direction (Figure $4 \mathrm{H}$ ). The centrifugal pumping force is the mechanical force that drives the filtrate through the membrane and is tangential to the flow direction. Once the filtrate is collected, it undergoes downstream analyses using quantitative room temperature, polymerase chain reaction (RT-PCR) for mRNA extraction, and ddPCR system for the simultaneous extraction of AR-V7 and AR-FL mRNA [134].

Notably, Peter Kuhn's lab developed the first AR-V7 CTC test for prostate from liquid biopsy using Epic CTC while he was at Scripps Research Institute in La Jolla, California[136] . The significant advantage of Kuhn's method is that it offers the unbiased approach of plating all 300 million cells on a blood draw on a slide, and combined with advanced information technology, grouped every individual cell on the slide to their respective coordinates $(X, Y)$ [136]. Epic platform also has the capability of providing comprehensive profiling of CTC, integrate with other existing technologies such as CellSearch, and downstream analyses of single cell at the genomic resolution level $[136,137]$.

\subsection{Techniques based on electrochemistry, surface plasmon resonance (SPR) and surface enhanced Raman scattering (SERS)} One of the attractive means of identifying and quantifying a bioanalytical target is direct conversion of a biological event to an electronic signal. Commonly used techniques for detection are cyclic voltammetry or differential pulse voltammetry, chronoamperometry, chronopotentiometry and impedance spectroscopy. Therefore, electrochemical techniques provide a valuable resource for rapid quantification of DNA, RNA, cancer cells, exosomes, and so forth. SPR or SERS are quantification techniques that are sometimes used as a complementary detection platform. Electrochemical detection techniques are extremely useful tools for analysing the redox state of chemical or biological systems, and third generation biosensors are increasingly explored for their high market potential, superior sensitivity, and nanoporous-mimicking enzyme fabrication for enhancing signal amplification [138].

SPR uses light to interrogate the interface nature of surface platforms and measure the adsorption of dynamic processes on thin films of gold, silver, or metal nanoparticles. It provides the basis for many color-based biosensors applications $[139,140]$. As an interface technique, 
SPR uses a monochromatic light on a surface to activate the charge-density of electrons (electrostatic potential) from modified metal surfaces. Examples of metal surfaces considered to be good candidates for optimal optical excitation of surface plasmons include gold, silver, copper, and aluminum. An interface with a dielectric medium is required for electrons to be available on a metal surface. A practical way of generating surface plasmons is using attenuated total reflection rather than a direct reflection technique or Kretschmann prism configuration [141, 142]. Therefore, real-time SPR applications for biospecific interaction analyses require (i) a biosensing surface immobilized on a metal surface as a coupling matrix, (ii) SPR optics for the convergence of incident light, (iii) a computer with an appropriate software package for the determination of the resonance angle, presentation and handling of data, and (iv) a simple microfluidic platform with a sample injection unit, rinsing and a regeneration unit, and all units must be fully automated to achieve a real-time SPR measurement [143].

Similarly, SERS is also an interface technique used for amplifying the Raman signals from molecules by several orders of magnitude. The amplification mainly comes from the interaction of electromagnetic light with molecules adsorbed onto metal surfaces, thereby producing large amplifications generally known as plasmon resonances [144].

\subsection{Nanoparticle-based electrochemical/SPR/SERS technologies for CTC application}

Wang et al. [145] have recently used a combined EC/SPR technique for label-free capture and detection of CTCs. They modified a glassy-carbon electrode with a plasmonic gold nanostars and then immobilized an aptamer probe directly on the surface. Based on direct plasmonenhanced electrochemistry, they were able to observe hybridization of plasmon concentrations at the star-shaped tips, producing an increased excitation of the nanoparticle material core and an enhancement of the electromagnetic field at the star-shaped tip. Based on this concept, the Wang group has immobilized the aptamer probe on a gold nanostar modified glassy carbon electrode to selectively capture the CTCs in blood samples, thus markedly enhancing the detection signal readout.

A multifunctional-based plasmonic application for photothermal destruction of CTC's has also been reported by Fan et al. [100]. Construction of the device required functionalization of a magnetic nanoparticle 'core' with a gold coating (as used for most aptameric modified surfaces) and attachment of a protein-specific aptamer for subsequent fluorescence imaging. The authors achieved isolation of specific cancer cells from the sample after attachment to the magnetic core with the aid of an external magnet. Cell death was initiated by irradiation of the 
magnetic beads with light of a specific wavelength whereupon the resultant localized optical heating resulted in cancer cell death (in that study: SKBR-3 cells). To confirm the experiment, dead cells were successfully stained with trypan blue - a dye that binds only to dead cells (and appears colorless under a bright field microscope). Thus, this method provides a highly selective, simple recognition platform that not only rapidly and efficiently isolates cancer cells but also can be used for imaging and qualitative determination of cell viability. The same group previously reported similar work using functionalized magnetic core-plasmonic shell star shaped nanoparticles for isolation of CTCs from whole blood samples [99].

Recently, a paper-based SERS device that also uses magnetic separation techniques has been used for cancer screening of colon cancer cells, normal cells and red blood cells present in a mixture. Each cell type was differentiated with high sensitivity and specificity, and the capture efficiency of cancer cells was $\Phi 8 \%$ [146]. The plasmonic paper-based process is illustrated in Figure 5. The plasmonic paper was fabricated by simply dipping laboratory filter paper in gold nanorod solution. In a parallel experiment, an immunomagnetic conjugate (antiEpCAM functionalized with magnetic beads) for cancer cell capture was purified with an external magnet, after incubation of a mixture of cancer cells, fibroblasts, and red blood cells. The enriched cells containing immunomagnetic conjugates were then transferred to the gold nanorod functionalized paper plasmonic material. Excitation of the paper surface with visible light ( at $633 \mathrm{~nm}$ ) produced SERS enhanced Raman spectra 'fingerprints' for the different cells. Another example of paper-based SERS for cancer detection involves a paper matrix impregnated with silver nanoparticles which has been used for clinical diagnosis of human papillomavirus - an infection associated with cervical cancer [147]. Therefore, paper based SERS approaches for CTC detection are cost effective, disposable, have minimum environmental impact and are mechanically advantageous as they have a large surface areas and are easily adopted for applications in microfluidic devices [146].

\section{Conclusions and future perspectives}

CTCs' extreme rarity, heterogeneous nature and varied phenotypicity remain major challenges for the development and application of new detection and therapeutic methods. Although the current state-of-the-art CellSearch ${ }^{\circledR}$ technology remains the only FDA approved test for clinical CTC enumeration, the technology has been unable to address many biological challenges

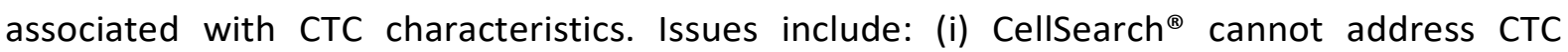
heterogeneity and phenotype variants requiring multiple markers for isolation and detection, (ii) the premise is built mostly on EPCAM as a universal biomarker for CTC enrichment, (iii) the 
method performs CTC enumeration regardless of whether CTC are damaged, single or clustered, and (iv) in the absence of an algorithm or software for differentiating phenotype variables, a CTC mixture will always be present in the count. Despite these drawbacks with CellSearch technology, integration with Diagnostic LeukApheresis has recently been reported to increase CTC yield and improve molecular tumor characterization [148]. Because most clinical CTC enumeration counts are not accurate, prognostic evaluation of patient samples remains largely conjectural. Thus, there is a critical need to reevaluate patient prognosis before and after treatment. Interestingly, several studies have examined CTCs along with other associated circulating markers, including circulating cell free DNA, exosomes and proteins within a given blood sample. Such a comprehensive platform provide means for understanding diagnosis, prognosis, and therapeutic treatment in disease management. There is also a critical issue regarding isolating and enriching low CTC concentrations in enough quantities without compromising their integrity during capture with a CTC device.

Integrated microfluidics developed for non-commercial and commercial systems are promising technologies for CTCs detection that have showed higher separation efficiencies. Though a few of these promising platforms still need improvement in cell clogging issues and low throughput. Overall, microfluidic system integrated with advanced computer systems may advance clinical research area rapidly.

Epic system is one of the most promising enrichment platforms. From a recent study [137], Epic technique was used to demonstrate unbiased characterisation and zero detection of 18 healthy donor samples, including establishing precision between multiple operators and using staining slide batches. The most attractive feature of the Epic platform is that it is amenable for downstream analysis including the analysis of single cell resolution.

Nanotheranostics for cancer outpatients is also envisaged to be the precision medicine of the future because it enables a single platform to be used in diagnostic, prognostic, and therapeutic treatment with accuracy. Interestingly, several paper-based SERS applications are promising candidates for rapid CTC detection, especially in remote, developing countries.

\section{Notes}

The concept of tumour cells translocating from a primary mass and invading locally in blood circulation was reported by Récamier (1829). Langenbeck's (1841) observations provided the first experimental evidence of tumour cells in blood circulation. Rudolph Virchow (1863) proposed the cellular origin of cancer and Thiersch (1865) developed the theory of growth energy imbalance in cancer. Australian physician, Thomas Ashworth (1869), documented the 
first evidence of epithelial cells in the blood of his deceased cancer patients, and consequently discovered CTCs. Three decades later, Stephen Paget (1889) proposed the seed-and-soil hypothesis of metastatic disease. In a series of autopsy studies, James Ewing (1920) showed the circulatory pattern to be the vehicle that controls primary tumour spread to secondary organ site, for example, breast cancer metastasising to bone, liver, brain, and lungs, or colorectal cancer (colon origin) metastasising in the liver. Other investigators also reported cases of metastasis not necessarily involving invasion of the vascular wall of the primary tumour and target organ. Watanabe Satoru (1954) discovered CTC clusters in jugular veins of mice after the injection of bronchogenic carcinoma cells. It was not until the 1990s that the clinical relevance of CTCs, along with other free circulating biomarkers in blood samples (liquid biopsy) received recognition as alternatives to frequent bone marrow biopsies The commentary notes can be found in the following references [8, 27, 37, 149-169].

Data accessibility. The authors confirm that all data supporting the findings of this study are already available within this paper.

Authors' contributions. V.A participated in the design of the study, coordinated the study and draft the manuscript; T.H.K coordinated the manuscript and helped draft the manuscript; C.L.B coordinated the manuscript and helped draft the manuscript; I.E.C. coordinated the study and helped draft the manuscript. All authors gave final approval for publication.

Competing interests. All authors declare no competing interest.

Funding. V.A acknowledges research grant from the Griffith University towards doctoral programme.

Acknowledgements. V.A would like to acknowledge the Griffith University for the GUPR and GUIPR scholarships.

\section{List of Abbreviations:}

CTC, circulating tumor cells; CTM, circulating tumor microemboli; DTC, disseminated tumor cells; EMT, epithelial-mesenchymal transition; MET, mesenchymal-epithelial transition HER2, human epithelial growth factor receptor 2; EGFR, epidermal growth factor receptor; CK, cytokeratin; WBC, white blood cells; ISET, isolation by size of epithelial cells; CAM, collagen adhesion matrix; iFISH, immuno-Fluorescence in situ Hybridization; eDAR, ensemble-decision aliquot ranking; HB-Chip, herringbone chip; DFF, dean flow fractionation; RBC, red blood cells; PEG, polyethylene glycol; FMSA, Flexible Micro Spring Array; $\mu$ CENSE, microfluidic centrifugal nanoparticles separation and extraction; SPR, surface plasmon resonance; EpCAM, epithelial 
cell adhesion molecule; SERS, surface enhanced Raman scattering; MUC1, mucin 1; CD45, also known as leukocyte antigen; ELISPOT, enzyme linked immunospot assay; ELISA, enzyme-linked immunosorbent assay; PBMCs, peripheral blood mononuclear cells; DAPI, 4,6-diamidino-2phenylindole; MNPs, magnetic nanoparticles; WBCs, white blood cells; FASTCell, fiber-optic array scanning technology; ${ }_{i}$ Chip, integrated chip; 2D and 3D, 2-dimension and 3-dimension; miDNA, micro DNA; miRNA, micro RNA; ARV-7, androgen-receptor splice variant 7; PCR, polymerase chain reaction.

Table 1: Molecular differentiation between normal and cancer cells with highlight on clinical relevance

\begin{tabular}{|c|c|c|c|}
\hline Molecular features & Normal Cells & Cancer Cells & Commentary/References \\
\hline $\begin{array}{l}\text { Cell cycle regulation } \\
\text { and apoptosis }\end{array}$ & Cell cycle are regulated. & $\begin{array}{l}\text { Genes responsible for cell } \\
\text { cycle control have been } \\
\text { deregulated. }\end{array}$ & $\begin{array}{l}\text { e.g. p53 tumour suppressor gene } \\
\text { [170] }\end{array}$ \\
\hline $\begin{array}{l}\text { Cell communication } \\
\text { through signal } \\
\text { transduction }\end{array}$ & $\begin{array}{l}\text { Cell-to-cell communication is } \\
\text { not autonomous but regulated } \\
\text { by functionalised proteins } \\
\text { responsible for growth factors } \\
\text { and ions that instruct cells to } \\
\text { grow and divide. }\end{array}$ & $\begin{array}{l}\text { Communicate efficiently when } \\
\text { in close contact (cluster } \\
\text { formation) through wrong } \\
\text { signal transduction, which } \\
\text { may trigger diabetes and } \\
\text { eventually lead to cancer. } \\
\text { Cancer cells also coordinate } \\
\text { their movement based on } \\
\text { cluster assembly, causing } \\
\text { individual cells to move away } \\
\text { from primary site to new site. }\end{array}$ & $\begin{array}{l}\text { Reparixin and other } \\
\text { related non-specific anti- } \\
\text { inflammatory drug agents } \\
\text { are currently tested in } \\
\text { clinical trials with cancer } \\
\text { patients. These drugs acts } \\
\text { as early therapeutic } \\
\text { intervention [171]. }\end{array}$ \\
\hline Appearance & $\begin{array}{l}\text { Shapes are usually defined with } \\
\text { a definite number of } \\
\text { chromosomes. }\end{array}$ & $\begin{array}{l}\text { Exhibit variable cell size with } \\
\text { no defined shape known as } \\
\text { aneuploidy cells. }\end{array}$ & \\
\hline Differentiation & $\begin{array}{l}\text { Regulated cell replication, } \\
\text { proliferation, and death }\end{array}$ & $\begin{array}{l}\text { Uninhibited cell replication } \\
\text { and proliferation. }\end{array}$ & $\begin{array}{l}\text { State of differentiation of cancer cells } \\
\text { correspond to the aggressiveness. }\end{array}$ \\
\hline Angiogenesis & $\begin{array}{l}\text { The process is regulated in a } \\
\text { healthy cell/ tissue. }\end{array}$ & $\begin{array}{l}\text { Growth of a new vascular } \\
\text { network around tumors is } \\
\text { hallmark of cancer growth, } \\
\text { essential for supporting tumor } \\
\text { cell proliferation and spread. }\end{array}$ & $\begin{array}{l}\text { Clinical use:angiogenesis } \\
\text { inhibitor medications } \\
{[172]}\end{array}$ \\
\hline Mutation & $\begin{array}{l}\text { Cells are regulated by the } \\
\text { different tumor suppressor } \\
\text { genes. }\end{array}$ & $\begin{array}{l}\text { Mutation process deactivates } \\
\text { tumor suppressor genes, } \\
\text { causing cells to grow } \\
\text { unchecked. }\end{array}$ & $\begin{array}{l}\text { Tumor suppressor genes regulate cell } \\
\text { cycle, repair damaged DNA and } \\
\text { apoptosis. }\end{array}$ \\
\hline Metabolism & $\begin{array}{l}\text { Major source of ATP is aerobic } \\
\text { cellular respiration. }\end{array}$ & $\begin{array}{l}\text { Reprogramming of energy } \\
\text { metabolism and increased } \\
\text { reliance on glycolysis due to } \\
\text { hypoxia. }\end{array}$ & $\begin{array}{l}\text { Clinical use: hyperbaric oxygen } \\
\text { treatments [173]. }\end{array}$ \\
\hline Telomeres & $\begin{array}{l}\text { Length of telomeres shortens as } \\
\text { cells age. Shortening of } \\
\text { telomeres signifies cell death or } \\
\text { end of a lifecycle of } \\
\text { that cell (apoptosis). }\end{array}$ & $\begin{array}{l}\text { Instead of telomeres being } \\
\text { shortened during cell division, } \\
\text { telomerase enzymes are } \\
\text { activated, inhibiting telomere } \\
\text { shortening and causing } \\
\text { cellular immortality. }\end{array}$ & $\begin{array}{l}\text { Clinical use: telomerase inhibitors are } \\
\text { considered as promising therapeutic } \\
\text { candidates [174]. }\end{array}$ \\
\hline Genomic instability & $\begin{array}{l}\text { Chromosomes are stable and } \\
\text { have a fixed total number. }\end{array}$ & $\begin{array}{l}\text { Cancer cells have increasingly } \\
\text { massive, abnormal DNA and } \\
\text { variable chromosomes, as the } \\
\text { cells are no longer regulated. }\end{array}$ & $\begin{array}{l}\text { Mutations in driver genes may make } \\
\text { cells cancerous. Clinical application : } \\
\text { development of therapies targeting } \\
\text { these driver genes [39]. }\end{array}$ \\
\hline
\end{tabular}




\begin{tabular}{|l|l|l|l|}
\hline Dormant & $\begin{array}{l}\text { By their nature, normal cells are } \\
\text { actively involved during their } \\
\text { entire life cycle until cell } \\
\text { apoptosis is attained. }\end{array}$ & $\begin{array}{l}\text { Certain tumor cells can resist } \\
\text { treatment and therefore } \\
\text { could lie dormant and go } \\
\text { undetected for } \\
\text { several years. }\end{array}$ & $\begin{array}{l}\text { Cancer stem cells possess this } \\
\text { attribute and it is an active area of } \\
\text { research. } \\
\text { Researchers are finding ways of } \\
\text { detecting these dormant cells and } \\
\text { destroying them [175]. }\end{array}$ \\
\hline
\end{tabular}

Table 2: CTCs Isolation/Enrichment Platforms

\begin{tabular}{|c|c|c|c|}
\hline $\begin{array}{l}\text { Isolation } \\
\text { technology }\end{array}$ & Principle & $\begin{array}{l}\text { Applications and technology } \\
\text { component category }\end{array}$ & References \\
\hline $\begin{array}{l}\text { Density Gradient } \\
\text { Centrifugation }\end{array}$ & $\begin{array}{l}\text { Physical process for isolating } \\
\text { mononuclear cells but with certain } \\
\text { amount of CTCs loss. }\end{array}$ & $\begin{array}{l}\text { Employed in preclinical and clinical } \\
\text { applications for cell separations. } \\
\text { OncoQuick, Percoll, and Ficoll- } \\
\text { Hypaque. Ficoll-Hypaque have been } \\
\text { used in the isolation of human } \\
\text { mesenchymal stem cells. }\end{array}$ & [176] \\
\hline $\begin{array}{l}\text { Other physical } \\
\text { separation techniques } \\
\text { e.g. ISET, Dean Flow } \\
\text { Fractionation, } \\
\text { ApoStream, DEPArray } \\
\text { (Fluidic) }\end{array}$ & $\begin{array}{l}\text { Principle is based on capture of } \\
\text { mononuclear cells using cell size } \\
\text { capacitance or electrical properties of } \\
\text { the device to isolate CTCs. }\end{array}$ & $\begin{array}{l}\text { They are fast and have high throughput } \\
\text { attributes like any other microfluidic } \\
\text { device, except for those that have been } \\
\text { identified with additional downstream } \\
\text { application. }\end{array}$ & \\
\hline $\begin{array}{l}\text { Immunomagnetic } \\
\text { separation }\end{array}$ & $\begin{array}{l}\text { Anti-EpCAM conjugated ferrofluidic } \\
\text { based nanoparticles are used for CTCs } \\
\text { enumeration. After cells are captured, } \\
\text { they are fluorescently labelled with } \\
\text { antibody-tagged cytokeratin nuclei dye } \\
\text { specific to positive CTCs. }\end{array}$ & $\begin{array}{l}\text { CellSearch is the only clinically } \\
\text { approved CTCs tool for monitoring CTC } \\
\text { count of patients' blood in breast } \\
\text { cancer, prostate, and colorectal cancer. }\end{array}$ & [95] \\
\hline Microfluidic & $\begin{array}{l}\text { The principle is based on manipulation } \\
\text { of fluid flow in micrometer or } \\
\text { nanometer scale, considering flexibility } \\
\text { of size control, geometry, and density } \\
\text { with precision. }\end{array}$ & $\begin{array}{l}\text { It is the most promising device for } \\
\text { analyzing blood samples, enumerating, } \\
\text { enriching, molecular profiling of CTCs } \\
\text { and other associated biomarkers. }\end{array}$ & $\begin{array}{l}{[93-95,102,104} \\
106,110]\end{array}$ \\
\hline
\end{tabular}

Table 3: Recognition Platforms

\begin{tabular}{l|lll}
\hline $\begin{array}{l}\text { Bioassays Capture } \\
\text { Technology }\end{array}$ & EpCAM+ & Applications & References \\
\hline CellSearch $^{\circledR}$ & EpCAM+ & $\begin{array}{l}\text { Device can process up to } 9 \mathrm{ml} \text { of blood per hour. The } \\
\text { device can also be used to enrich target cells, eliminate }\end{array}$ \\
\hline MagSweeper & [90] \\
\hline
\end{tabular}




\begin{tabular}{|c|c|c|c|}
\hline & & $\begin{array}{l}\text { unbound cells and the process does not perturb gene } \\
\text { expression of cells. }\end{array}$ & \\
\hline AdnaTest & $\begin{array}{l}\text { EpCAM+, gene } \\
\text { markers by RT-PCR }\end{array}$ & $\begin{array}{l}\text { In addition of Adna Test being complementary to EpCAM, } \\
\text { it also has wide clinical applications for gene detection, } \\
\text { multiplex-PCR and fluorescence in situ hybridization. }\end{array}$ & [95] \\
\hline IsoFlux & $\begin{array}{l}\text { EpCAM+, MUC1, } \\
\text { Mesothelin }\end{array}$ & $\begin{array}{l}\text { High recovery cell enumeration rate as compared to } \\
\text { CellSearch": } 95 \%: 36 \% \text { respectively; also used for tracking } \\
\text { oncogene mutational changes. }\end{array}$ & [96] \\
\hline GILUPI CellCollector & EpCAM+ & $\begin{array}{l}\text { In vivo CTC enrichment for monitoring patient. The device } \\
\text { is portable and safe when used as a functionalized wire }\end{array}$ & [91] \\
\hline EPISOT assay & $\begin{array}{l}\text { Epithelial secreting } \\
\text { cells and CD45+ } \\
\text { depletion }\end{array}$ & $\begin{array}{l}\text { Device can be used to screen viable epithelial cells. The } \\
\text { device is unbiased towards } \\
\text { CTC/DTC phenotypes enrichment. }\end{array}$ & [89] \\
\hline CAM assay & EpCAM+ & $\begin{array}{l}\text { CAM assay favors the isolation of CTCs with collagen } \\
\text { invasive phenotype. }\end{array}$ & [67] \\
\hline ELISPOT & $\begin{array}{l}\text { Cells secreting } \\
\text { specific antibody }\end{array}$ & More reliable for ex-vivo simulated PBMC than ELISA. & [177] \\
\hline Vita-Assay ${ }^{\top M}$ & $\begin{array}{l}\text { Functional capture of } \\
\text { CAM+ }\end{array}$ & $\begin{array}{l}\text { Successfully utilized for ex-vivo drug-sensitivity testing of } \\
\text { ovarian-cancer patient CTCs. } \\
\text { Other applications include multiplex cytometric detection } \\
\text { in breast, ovary, prostate, pancreas, colorectum and lung } \\
\text { cancer. }\end{array}$ & {$[178,179]$} \\
\hline$\mu \mathrm{H}$ all detector assay & $\begin{array}{l}\text { Simultaneous EGFR+, } \\
\text { HER2+ and EPCAM+ }\end{array}$ & $\begin{array}{l}\text { It can be used for clinical enumeration of rare cells, with } \\
\text { the possibility of detecting multiple biomarkers. The } \\
\text { sensitivity of the device as a cell counter is better than } \\
\text { existing devices, making it a potential device for CTCs } \\
\text { enumeration count and detection of TNBC in cancer } \\
\text { patients. }\end{array}$ & {$[180]$} \\
\hline Ephesia CTC chip & EpCAM+ & $\begin{array}{l}\text { The technology combines immunomagnetic capture and } \\
\text { the best aspects of microfluidic features. It is compact, } \\
\text { fully automated, high purity capture, with sample } \\
\text { retrieval for further genetic profiling } \\
\text { The device has potential to non-invasively monitor CTC } \\
\text { progression and drug-resistant mutation. }\end{array}$ & [181] \\
\hline Vortex micromixers & EpCAM+,CD45+ & $\begin{array}{l}\text { Mutli-vortex micromixing can be used for improving } \\
\text { binding interaction between antibodies and MNP. The } \\
\text { magnetic sorter increases selection for targets captured. } \\
\text { The device has the optional route for depleting WBCs and } \\
\text { enriching heterogeneous CTCs population with minimal } \\
\text { CTCs loss. }\end{array}$ & [182] \\
\hline FASTCell & CK, CD45-, DAPI & $\begin{array}{l}\text { The device can be used to locate immunofluorescently- } \\
\text { labelled rare cells on glass substrates, with scan rates } \times \\
500 \text { faster than automated digital microscopy. }\end{array}$ & \\
\hline
\end{tabular}

Table 4: Comprehensive Summary of CTCs and Technology Platforms

\begin{tabular}{l|l|l|l}
\hline CTCs challenges & Opportunities & Strengths & Weaknesses \\
\hline $\begin{array}{l}\text { CTCs are rare, present in } \\
\text { extreme low }\end{array}$ & $\begin{array}{l}\text { Establishment of a more } \\
\text { robust and reproducible }\end{array}$ & $\begin{array}{l}\text { There are many CTCs technology platforms that } \\
\text { can potentially monitor CTC count of patients' } \\
\text { blood in real-time. }\end{array}$ & $\begin{array}{l}\text { Most CTC-based assays } \\
\text { present low sensitivity, } \\
\text { increasing patients at }\end{array}$ \\
\hline
\end{tabular}




\begin{tabular}{|c|c|c|c|}
\hline $\begin{array}{l}\text { amidst millions of red } \\
\text { blood cells and billions of } \\
\text { white blood cells [184, } \\
185] \text {. }\end{array}$ & $\begin{array}{l}\text { disease management } \\
\text { from early detection to } \\
\text { the development of } \\
\text { targeted therapies. }\end{array}$ & & $\begin{array}{l}\text { high risk of developing } \\
\text { metastasis. }\end{array}$ \\
\hline $\begin{array}{l}\text { CTCs are highly } \\
\text { heterogeneous, with } \\
\text { phenotypic traits that are } \\
\text { also distinct }[186,187] .\end{array}$ & $\begin{array}{l}\text { More relevant studies } \\
\text { should focus on the } \\
\text { development of omics- } \\
\text { based CTC studies at } \\
\text { single cell. }\end{array}$ & $\begin{array}{l}\text { One of the ways of monitoring advanced stage } \\
\text { cancer patients is monitoring the positive CTCs } \\
\text { count, which equate to poor prognosis. }\end{array}$ & $\begin{array}{l}\text { With CellSearch as the } \\
\text { only approved } \\
\text { enumerating tool for } \\
\text { CTCs count limits the } \\
\text { capture of other CTCs } \\
\text { phenotypes present. }\end{array}$ \\
\hline $\begin{array}{l}\text { CTCs are highly } \\
\text { vulnerable and easily } \\
\text { damaged }[21,46,48] \text {. }\end{array}$ & $\begin{array}{l}\text { One of the ways of } \\
\text { studying viability of cells } \\
\text { captured is the } \\
\text { development of ex vivo } \\
\text { models. }\end{array}$ & $\begin{array}{l}\text { Although the mechanism of cancer } \\
\text { heterogeneity and phenotypic traits is } \\
\text { inexplicable, the advent of machine learning } \\
\text { algorithm such as Bayesian Classifier and gene } \\
\text { selection classifier have opened up new } \\
\text { opportunities for understanding CTCs } \\
\text { characteristics. }\end{array}$ & $\begin{array}{l}\text { There is a scarce } \\
\text { information on the } \\
\text { molecular nature of } \\
\text { single CTC, thus } \\
\text { hindering the } \\
\text { development of effective } \\
\text { analytical platforms. }\end{array}$ \\
\hline $\begin{array}{l}\text { Captured cells must be } \\
\text { pure and viable. Also, } \\
\text { captured cells that are } \\
\text { stained do not } \\
\text { necessarily equate to } \\
\text { viable cells }[46,86,188] \text {. }\end{array}$ & $\begin{array}{l}\text { More relevant } \\
\text { information is needed in } \\
\text { pre-metastatic and } \\
\text { metastatic niches. }\end{array}$ & $\begin{array}{l}\text { Nanomaterials-based assays represent the } \\
\text { foremost cutting edge technology for } \\
\text { revolutionizing precision medicine of the future } \\
\text { as they exhibit excellent signal transducing } \\
\text { capabilities for amplifying signal readout, high } \\
\text { ultrasensitive responses and they are } \\
\text { remarkably suited for applications requiring high } \\
\text { biorecognition platforms for producing excellent } \\
\text { optical, electrochemical and plasmonic } \\
\text { responses. }\end{array}$ & $\begin{array}{l}\text { Clinical implementation } \\
\text { is hindered by lack of } \\
\text { standardized methods } \\
\text { for CTCs analysis. }\end{array}$ \\
\hline $\begin{array}{l}\text { CellSearch targets only } \\
\text { EpCAM+, this is true for } \\
\text { most recognition } \\
\text { platforms } \\
{[5,46,87]}\end{array}$ & $\begin{array}{l}\text { Nanotheranostics } \\
\text { research area may } \\
\text { revolutionize } \\
\text { personalized precision } \\
\text { management for cancer } \\
\text { patient. }\end{array}$ & $\begin{array}{l}\text { Gold nanoparticles-based assays have been } \\
\text { tested with clinical samples for circulating } \\
\text { cancer marker detection as having superior } \\
\text { assay performance to most commercially } \\
\text { available assays. }\end{array}$ & $\begin{array}{l}\text { Based on the current } \\
\text { clinical studies, a huge } \\
\text { gap exists in the } \\
\text { molecular understanding } \\
\text { and translation of CTCs } \\
\text { analysis }\end{array}$ \\
\hline $\begin{array}{l}\text { Most CTC platforms lack } \\
\text { the robust and } \\
\text { reproducible methods } \\
\text { for translating CTC } \\
\text { dynamics and molecular } \\
\text { heterogeneity [5]. }\end{array}$ & $\begin{array}{l}\text { Potential opportunities in } \\
\text { microfluidic based } \\
\text { technology as POC } \\
\text { systems will help reduce } \\
\text { cost for medical } \\
\text { treatments. }\end{array}$ & $\begin{array}{l}\text { Plasmonic paper-based microfluidics systems for } \\
\text { cancer research have potential utility in research } \\
\text { labs, clinics and in remote non-laboratory } \\
\text { settings, as sample volumes are reduced, and } \\
\text { detection tests can rapidly be carried out. } \\
\text { Overall cost for the development of such } \\
\text { platforms are considerably cheaper to most CTC } \\
\text { technologies. }\end{array}$ & $\begin{array}{l}\text { Strong collaboration at } \\
\text { the interdisciplinary and } \\
\text { multidisciplinary level is } \\
\text { lacking. Hence, there is } \\
\text { the need for bridging the } \\
\text { knowledge gap in CTCs } \\
\text { field. }\end{array}$ \\
\hline $\begin{array}{l}\text { Single CTC analysis } \\
\text { captured for instance by } \\
\text { DEP-based technology } \\
\text { excludes considerable } \\
\text { heterogeneity present at } \\
\text { a single CTC level } \\
{[48,189] .}\end{array}$ & $\begin{array}{l}\text { Development of novel } \\
\text { nanomaterials for } \\
\text { performing highly } \\
\text { multiplexed detection } \\
\text { and molecular profiling } \\
\text { of CTCs heterogeneity } \\
\text { and triple negative } \\
\text { breast cancer research } \\
\text { will also help reduce cost } \\
\text { medical costs. }\end{array}$ & $\begin{array}{l}\text { Integration of imprintable theranostic magnetic } \\
\text { core including plasmonic shell star shape } \\
\text { nanoparticle-based assays into paper } \\
\text { microfluidic technology for multiplexed } \\
\text { detection demonstrate some of the } \\
\text { attainments of CTCs technology. }\end{array}$ & $\begin{array}{l}\text { Most microfluidic } \\
\text { platforms present 2D } \\
\text { model solids. However, } \\
\text { with imprintable 3D and } \\
\text { 4D* mechano-responsive } \\
\text { environments, } \\
\text { microfluidic devices and } \\
\text { cell culture model } \\
\text { expansion for culturing } \\
\text { CTCs heterogeneity will } \\
\text { lead to unprecedented } \\
\text { breakthroughs, and } \\
\text { better understanding of } \\
\text { CTC characteristics. }\end{array}$ \\
\hline $\begin{array}{l}\text { Preclinical studies utilize } \\
\text { cells grown on 2D culture } \\
\text { that are mostly flat, } \\
\text { whereas a 3D culture } \\
\text { grows upward in the z } \\
\text { direction, known to } \\
\text { mimic the physiologic } \\
\text { cell environment. This } \\
\text { may also contribute to } \\
\text { the reason why most } \\
\text { drugs fail during the } \\
\text { preclinical phase [190]. }\end{array}$ & $\begin{array}{l}\text { Other areas of CTCs } \\
\text { technology development } \\
\text { should focus on critical } \\
\text { clinical relevance. }\end{array}$ & $\begin{array}{l}\text { Barcoded assays integrated with either metallic } \\
\text { or micro/nanomaterials for multiplexed disease } \\
\text { testing and diagnostics is also another } \\
\text { technology that is rapidly increasing. These } \\
\text { devices have the capabilities of broadening } \\
\text { encoding barcode libraries information for } \\
\text { multiplexed assays for batch processing for } \\
\text { simultaneous detection and thereby reducing } \\
\text { time and cost for detection of biomarker. } \\
\text { Strategies for assembling the device enables } \\
\text { room for: multiplexing, optical encoding, } \\
\text { molecular tags and imaging, diversity in color } \\
\text { visualization for genetic encoding and graphical }\end{array}$ & $\begin{array}{l}\text { The comprehensive } \\
\text { profiling of CTCs either } \\
\text { directly from cultured } \\
\text { cells or from patients' } \\
\text { sample is urgently } \\
\text { required as this } \\
\text { represents cancer } \\
\text { aetiology. }\end{array}$ \\
\hline
\end{tabular}




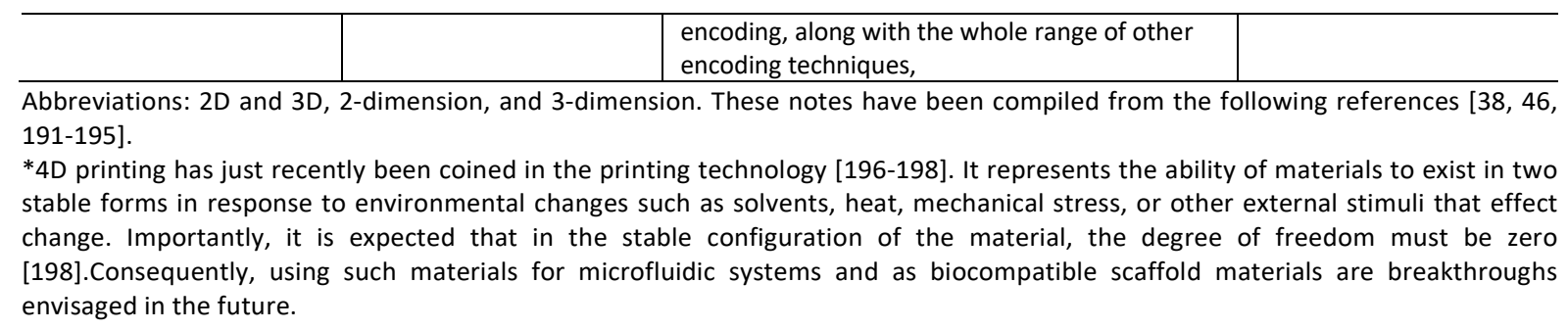

\section{Figures and captions:}

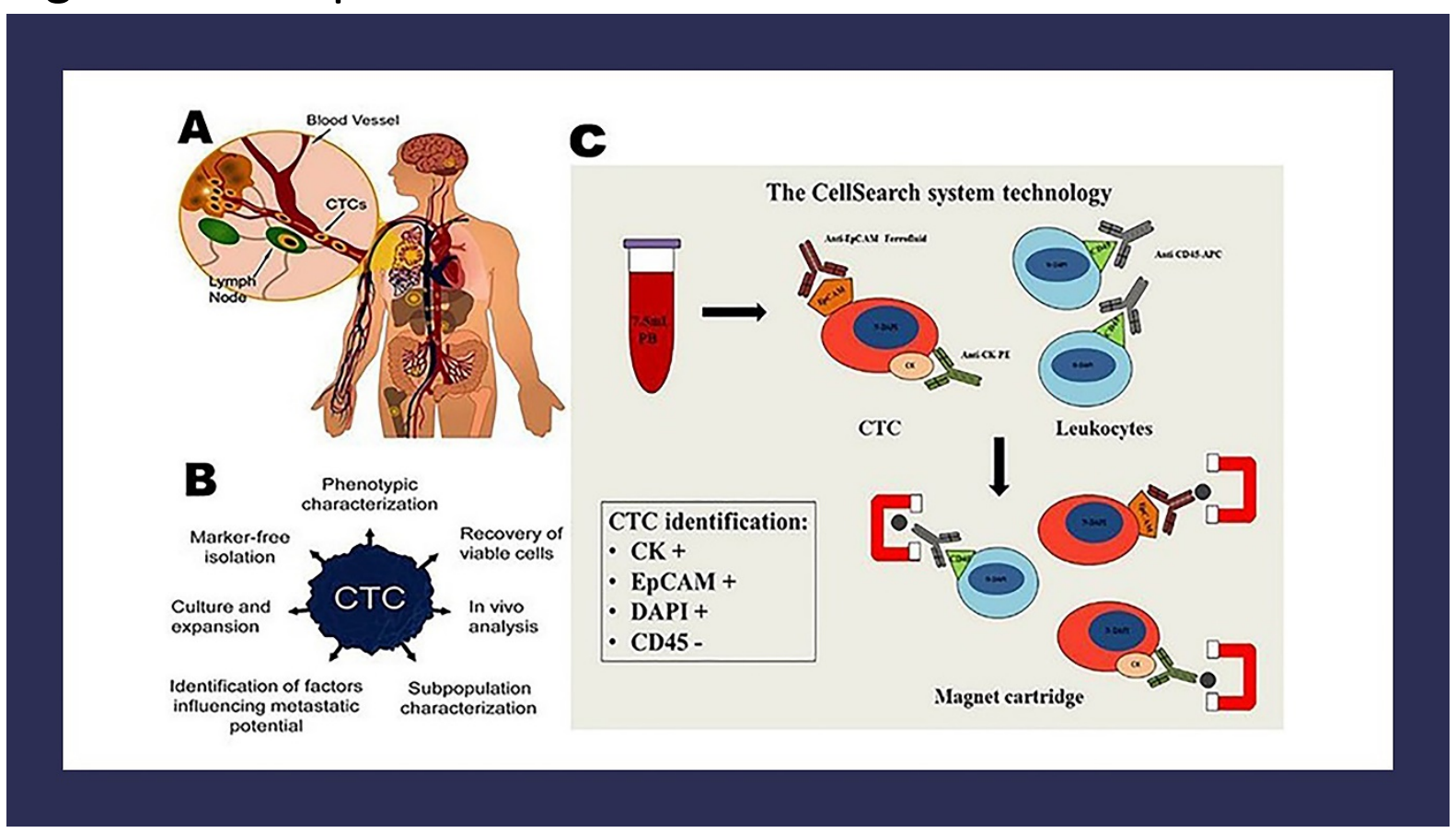

Figure 1. Circulating tumor cells (CTCS): A. CTCs released into the bloodstream. B. CTCs profiling considered as emerging areas of research. C. Schematic representation of CellSearch tool and preselection markers currently identified by the technology. CellSearch also has a size demarcation for CTCs based on certain nuclear/cytoplasmic volume. Figures 1: A and B : reproduced with permission from [49]Copyright (c) 2016, Wiley-VCH Verlag GmbH \& Co. KGaA, Weinheim. Figure 1C is reproduced under the Creative Commons Attribution License (CC BY) with permission from [199] (C) 2014 Frontiers Media S.A. 
(a)

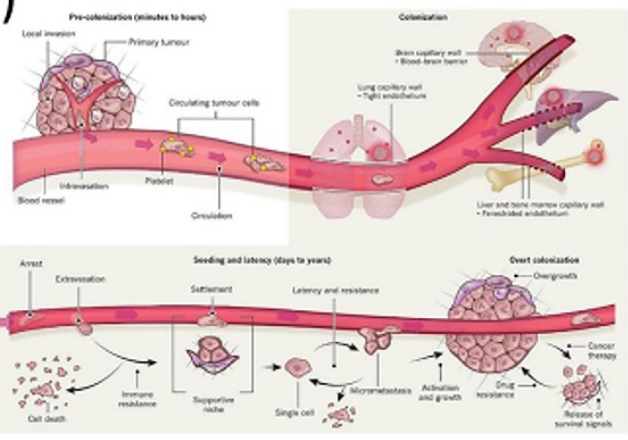

\section{Key processes for CTCS}

The key cellular process involves

(1) Intravasation;

(2) Extratravasation to bone marrow or to other organs

(3) Cell dissemination

(4) Metastasis (b)

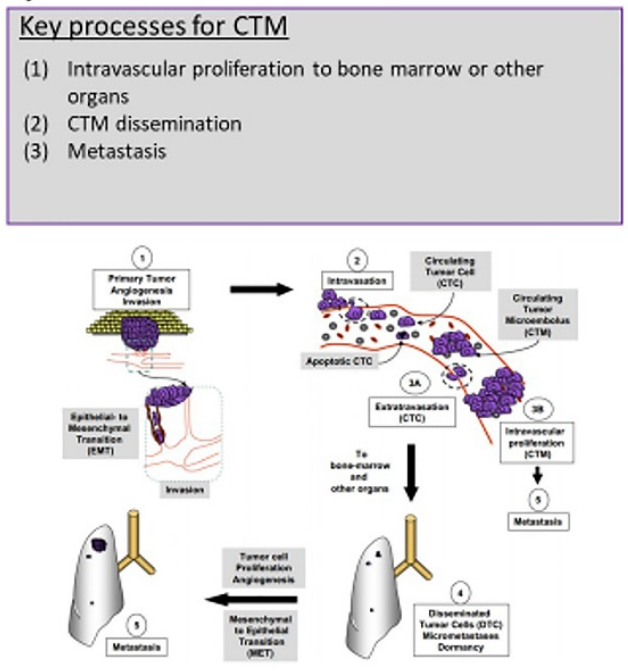

Figure 2. CTCs/CTM invasion stages: Figure 2(a) reproduced with permission from [38] Copyright (C) 2016, Macmillan Publishers Limited. Figure 2(b) reproduced with permission from [3] Copyright (C) Elsevier

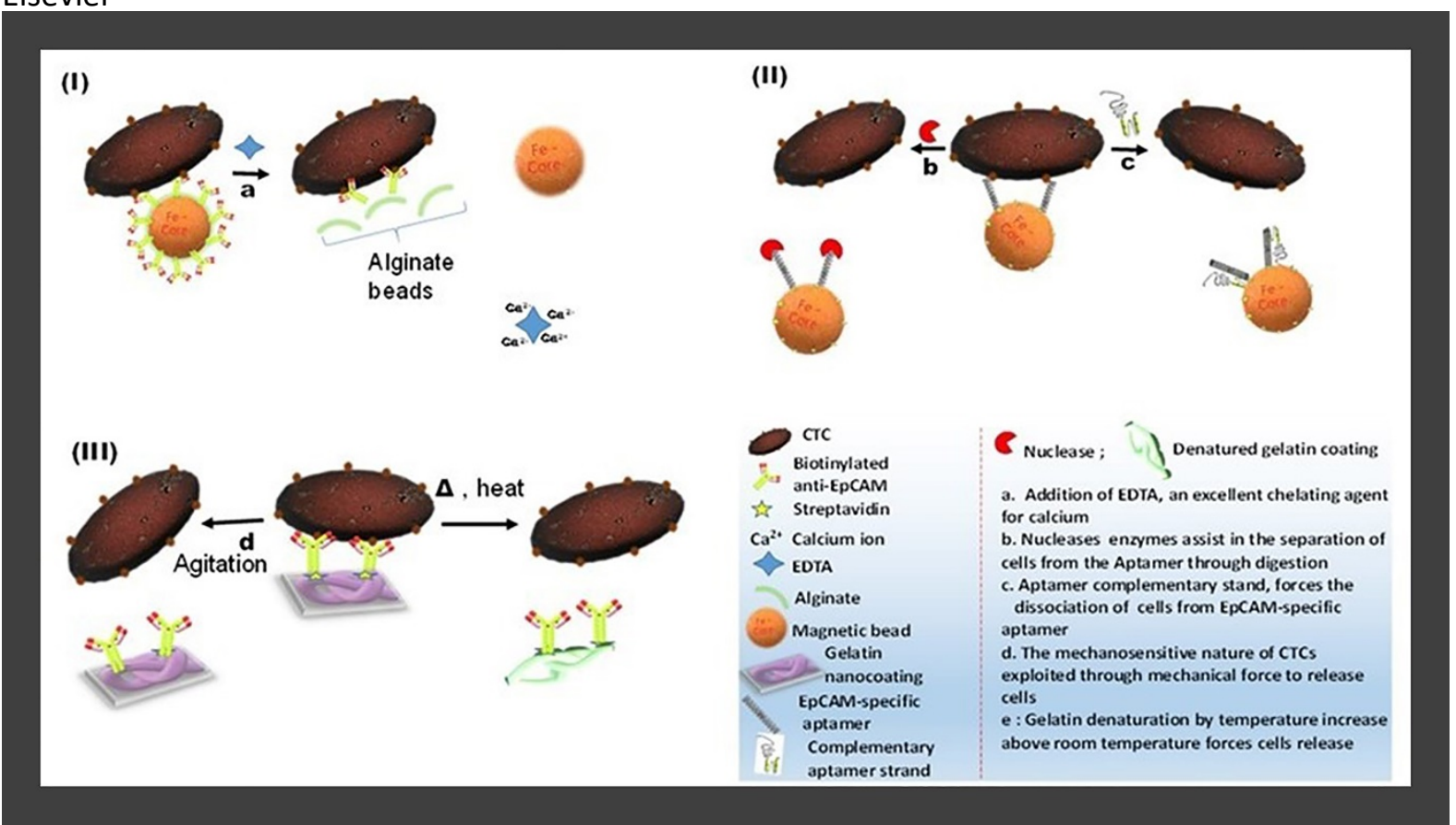

Figure 3. Modes of CTC release with aptamer-based platforms. Scheme redrawn from[49]. 


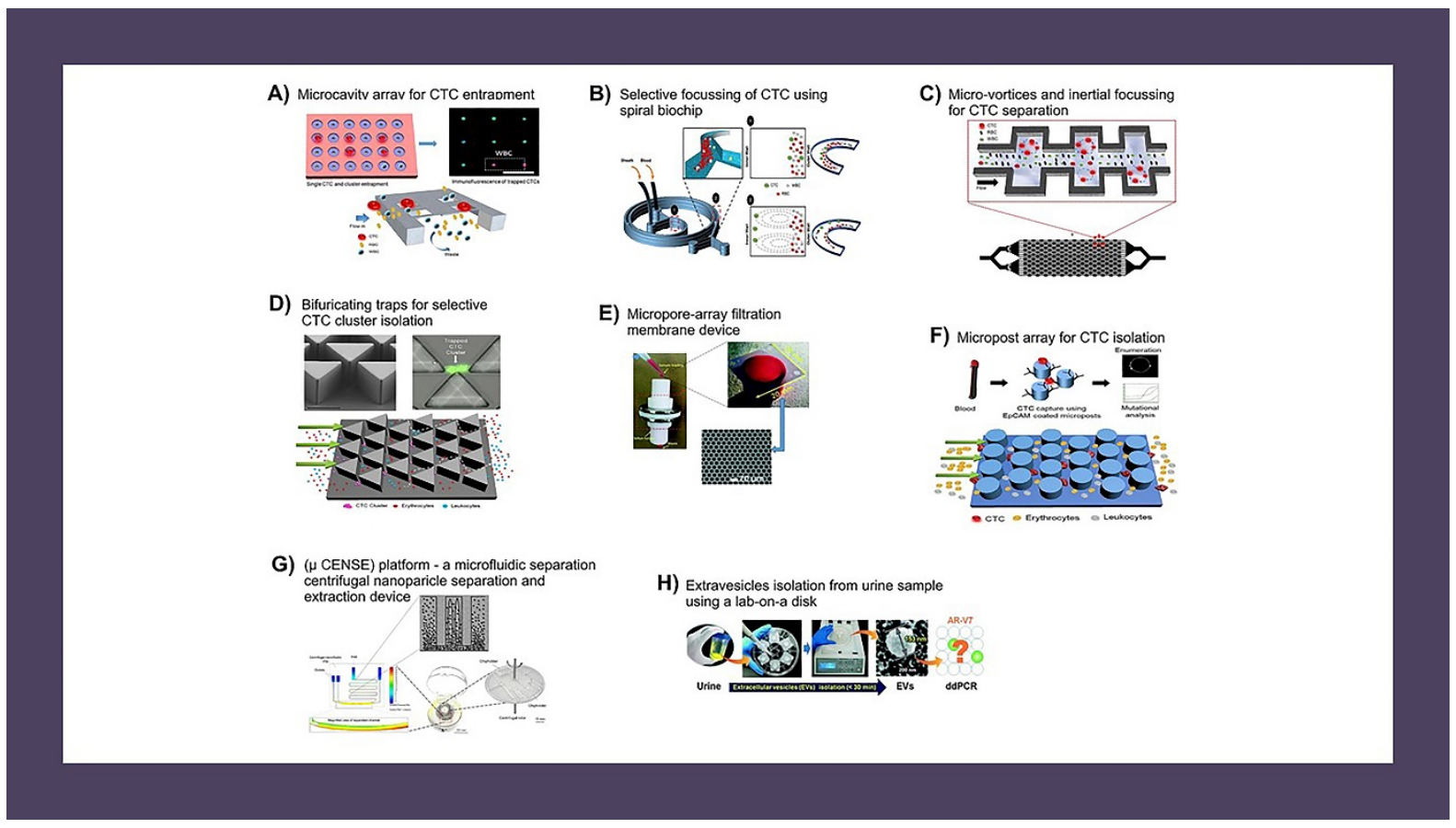

Figure 4. CTCs platforms. (A) Microcavity Array; (B) Spiral Biochip ; (C) Vortex Chip; (D) Cluster-Chip ; (E) Micropore array filtration device; (F) Micropost Array; (G) $\mu$ CENSE device; (H) Lab-on-a-disc. Figure 4 (A-D, F) reproduced with permission from \{Umer, 2018 \#254\} Copyright (C) 2018, Elsevier. Figure 4: E) reproduced with permission from [200] Copyright (C) 2019, The Royal Society of Chemistry; G) Adapted and reproduced with permission from [128] Copyright (C) 2018, AIP Publishing; H) reproduced with permission from [134] Copyright (C) 2019, The Royal Society of Chemistry.

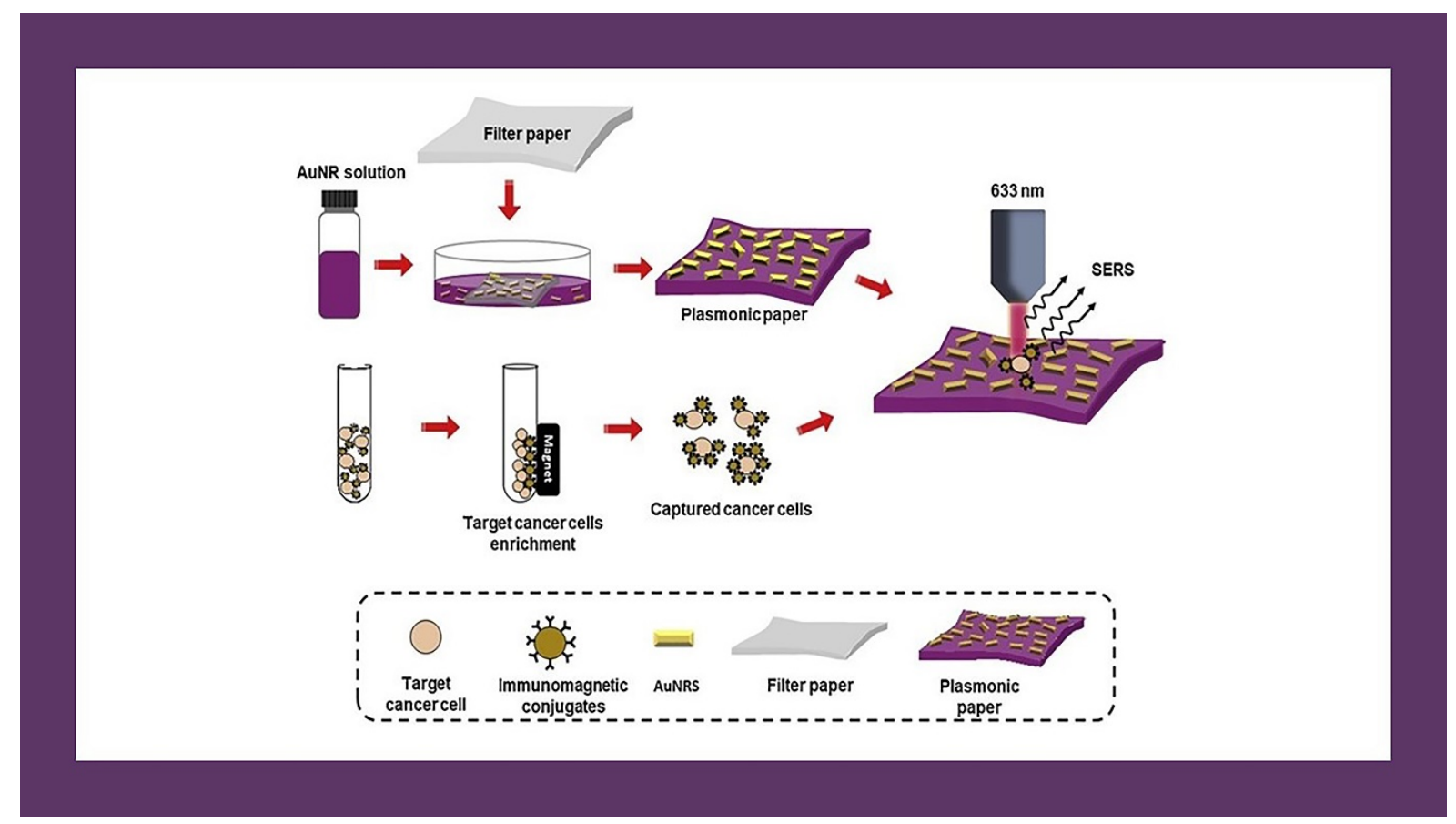

Figure 5. Paper based plasmonic application for cancer cells detection with the assistance of magnetic enrichment. Reproduced with permission from [146] Copyright (C) 2019, Elsevier. 


\section{References}

[1] Andree, K.C. 2016 Challenges in circulating tumor cell detection by the CellSearch system. Molecular oncology 10, 395-407.

[2] Micalizzi, D.S., Maheswaran, S. \& Haber, D.A. 2017 A conduit to metastasis: circulating tumor cell biology. Genes \& development 31, 1827-1840.

[3] Paterlini-Brechot, P. \& Benali, N.L. 2007 Circulating tumor cells (CTC) detection: clinical impact and future directions. Cancer letters 253, 180-204.

[4] Padmanaban, V., Krol, I., Suhail, Y., Szczerba, B.M., Aceto, N., Bader, J.S. \& Ewald, A.J. 2019 Ecadherin is required for metastasis in multiple models of breast cancer. Nature 573, 439-444.

[5] Krebs, M.G. 2014 Molecular analysis of circulating tumour cells-biology and biomarkers. Nature reviews. Clinical oncology 11, 129-144.

[6] Polzer, B. 2014 Molecular profiling of single circulating tumor cells with diagnostic intention. EMBO molecular medicine 6, 1371-1386.

[7] Tellez-Gabriel, M., Cochonneau, D., Cadé, M., Jubelin, C., Heymann, M.-F. \& Heymann, D. 2019 Circulating Tumor Cell-Derived Pre-Clinical Models for Personalized Medicine. Cancers 11, 19.

[8] Cristofanilli, M., Budd, G.T., Ellis, M.J., Stopeck, A., Matera, J., Miller, M.C., Reuben, J.M., Doyle, G.V., Allard, W.J. \& Terstappen, L.W. 2004 Circulating tumor cells, disease progression, and survival in metastatic breast cancer. New England Journal of Medicine 351, 781-791.

[9] Meyer, C.P. 2016 Limited prognostic value of preoperative circulating tumor cells for early biochemical recurrence in patients with localized prostate cancer. Urologic oncology 34, 235.e211235.e216.

[10] Wit, S.d. 2015 The detection of EpCAM and EpCAM- circulating tumor cells. Scientific reports 5. [11] Janni, W.J. 2016 Pooled Analysis of the Prognostic Relevance of Circulating Tumor Cells in Primary Breast Cancer. Clinical cancer research 22, 2583-2593.

[12] Bahnassy, A.A. 2019 Prognostic significance of circulating tumor cells (CTCs) in Egyptian nonmetastatic colorectal cancer patients: A comparative study for four different techniques of detection (Flowcytometry, CellSearch, Quantitative Real-time PCR and Cytomorphology). Experimental and molecular pathology 106, 90-101.

[13] Beije, N. 2015 Circulating tumor cell enumeration by the CellSearch system: The clinician's guide to breast cancer treatment? Cancer treatment reviews 41, 144-150.

[14] Krebs, M.G., Sloane, R., Priest, L., Lancashire, L., Hou, J.-M., Greystoke, A., Ward, T.H., Ferraldeschi, R., Hughes, A. \& Clack, G. 2011 Evaluation and prognostic significance of circulating tumor cells in patients with non-small-cell lung cancer. Journal of clinical oncology 29, 1556-1563.

[15] Naito, T., Tanaka, F., Ono, A., Yoneda, K., Takahashi, T., Murakami, H., Nakamura, Y., Tsuya, A., Kenmotsu, H. \& Shukuya, T. 2012 Prognostic impact of circulating tumor cells in patients with small cell lung cancer. Journal of Thoracic Oncology 7, 512-519.

[16] Normanno, N., Rossi, A., Morabito, A., Signoriello, S., Bevilacqua, S., Di Maio, M., Costanzo, R., De Luca, A., Montanino, A. \& Gridelli, C. 2014 Prognostic value of circulating tumor cells' reduction in patients with extensive small-cell lung cancer. Lung Cancer 85, 314-319.

[17] Wit, S.d. 2017 Abstract 3787: EpCAM- and EpCAM circulating tumor cells in metastatic prostate and breast cancer patients: a multicenter study. Cancer research (Chicago, III.) 77, 3787-3787.

[18] Xu, L., Mao, X., Imrali, A., Syed, F., Mutsvangwa, K., Berney, D., Cathcart, P., Hines, J., Shamash, J. \& Lu, Y.-J. 2015 Optimization and evaluation of a novel size based circulating tumor cell isolation system. PloS one 10, e0138032.

[19] Kulasinghe, A., Kenny, L., Perry, C., Thiery, J.-P., Jovanovic, L., Vela, I., Nelson, C. \& Punyadeera, C. 2016 Impact of label-free technologies in head and neck cancer circulating tumour cells. Oncotarget 7, 71223. 
[20] Kulasinghe, A., Hughes, B.G., Kenny, L. \& Punyadeera, C. 2019 An update: circulating tumor cells in head and neck cancer. Expert Review of Molecular Diagnostics 19, 1109-1115.

[21] Akhtar, M., Haider, A., Rashid, S. \& Al-Nabet, A.D.M. 2019 Paget's "Seed and Soil" Theory of Cancer Metastasis: An Idea Whose Time has Come. Advances in anatomic pathology 26, 69-74.

[22] Fidler, I. 1973 Selection of successive tumour lines for metastasis. Nature New Biology 242, 148149.

[23] Fidler, I.J. 1970 Metastasis: quantitative analysis of distribution and fate of tumor emboli labeled with 125I-5-iodo-2'-deoxyuridine. Journal of the National Cancer Institute 45, 773-782.

[24] Fidler, I.J. 1995 Modulation of the organ microenvironment for treatment of cancer metastasis. JNCI: Journal of the National Cancer Institute 87, 1588-1592.

[25] Fidler, I.J. 1995 Critical factors in the biology of human cancer metastasis. The American surgeon 61, 1065-1066.

[26] Fidler, I.J. 2002 The organ microenvironment and cancer metastasis. Differentiation 70, 498-505.

[27] Fidler, I.J. 2003 The pathogenesis of cancer metastasis: the'seed and soil'hypothesis revisited. Nature Reviews Cancer 3, 453.

[28] Fidler, I.J. \& Hart, I.R. 1982 Biological diversity in metastatic neoplasms: origins and implications. Science 217, 998-1003.

[29] Fidler, I.J. \& Kripke, M.L. 1977 Metastasis results from preexisting variant cells within a malignant tumor. Science 197, 893-895.

[30] Fidler, I.J. \& Poste, G. 2008 The "seed and soil" hypothesis revisited. The lancet oncology 9, 808.

[31] Fidler, I.J., Yano, S., Zhang, R.-d., Fujimaki, T. \& Bucana, C.D. 2002 The seed and soil hypothesis: vascularisation and brain metastases. The lancet oncology 3, 53-57.

[32] Talmadge, J.E. \& Fidler, I. 1982 Evidence for the clonal origin of spontaneous metastases. Science 217, 361-363.

[33] Aceto, N., Bardia, A., Miyamoto, D.T., Donaldson, M.C., Wittner, B.S., Spencer, J.A., Yu, M., Pely, A., Engstrom, A. \& Zhu, H. 2014 Circulating tumor cell clusters are oligoclonal precursors of breast cancer metastasis. Cell 158, 1110-1122.

[34] Mullikin, T.C., Rajkumar, S.V., Dispenzieri, A., Buadi, F.K., Lacy, M.Q., Lin, Y., Dingli, D., Go, R.S., Hayman, S.R. \& Zeldenrust, S.R. 2016 Clinical characteristics and outcomes in biclonal gammopathies. American journal of hematology 91, 473-475.

[35] Jolly, M.K., Boareto, M., Debeb, B.G., Aceto, N., Farach-Carson, M.C., Woodward, W.A. \& Levine, H. 2017 Inflammatory breast cancer: a model for investigating cluster-based dissemination. NPJ Breast Cancer 3, 1-8.

[36] Krol, I., Castro-Giner, F., Maurer, M., Gkountela, S., Szczerba, B.M., Scherrer, R., Coleman, N., Carreira, S., Bachmann, F. \& Anderson, S. 2018 Detection of circulating tumour cell clusters in human glioblastoma. British journal of cancer 119, 487-491.

[37] Hong, Y., Fang, F. \& Zhang, Q. 2016 Circulating tumor cell clusters: What we know and what we expect. International journal of oncology 49, 2206-2216.

[38] Massagué, J. \& Obenauf, A.C. 2016 Metastatic colonization by circulating tumour cells. Nature 529, 298. (doi:10.1038/nature17038).

[39] Yochum, Z.A., Cades, J., Wang, H., Chatterjee, S., Simons, B.W., O’Brien, J.P., Khetarpal, S.K., Lemtiri-Chlieh, G., Myers, K.V. \& Huang, E.H.-B. 2019 Targeting the EMT transcription factor TWIST1 overcomes resistance to EGFR inhibitors in EGFR-mutant non-small-cell lung cancer. Oncogene 38, 656.

[40] Cahall, C.F., Lilly, J.L., Hirschowitz, E.A. \& Berron, B.J. 2015 A quantitative perspective on surface marker selection for the isolation of functional tumor cells. Breast cancer: basic and clinical research 9, BCBCR. S25461.

[41] Brabletz, T. 2018 EMT in cancer. Nature reviews. Cancer 18, 128-134.

[42] Kazan, J. 2019 Cx43 Expression Correlates with Breast Cancer Metastasis in MDA-MB-231 Cells In Vitro, In a Mouse Xenograft Model and in Human Breast Cancer Tissues. Cancers 11. 
[43] Jin, H. 2004 Integrins: roles in cancer development and as treatment targets. British journal of cancer $90,561-565$.

[44] Thomas, J., Moore, K., Sproat, C., Maldonado, H., Mo, S., Haider, S., Hammond, D., Thomas, G., Prior, I. \& Cutillas, P. 2018 Integrin $\alpha$ V $\beta 6$-EGFR crosstalk regulates bidirectional force transmission and controls breast cancer invasion.

[45] Pollard, J.W. 2016 Defining metastatic cell latency. New England Journal of Medicine 375, 280282.

[46] den Toonder, J. 2011 Circulating tumor cells: the Grand Challenge. Lab on a chip 11, 375-377.

[47] Paoletti, C., Li, Y., Muñiz, M.C., Kidwell, K.M., Aung, K., Thomas, D.G., Brown, M., Abramson, V., Irvin, W.J. \& Lin, N.U. 2015 Significance of circulating tumor cells in metastatic triple negative breast cancer patients within a randomized, phase II trial: TBCRC 019. Clinical cancer research, clincanres. 2781.2014.

[48] Song, Y., Tian, T., Shi, Y., Liu, W., Zou, Y., Khajvand, T., Wang, S., Zhu, Z. \& Yang, C. 2017 Enrichment and single-cell analysis of circulating tumor cells. Chemical science 8, 1736-1751.

[49] Green, B.J. 2016 Beyond the Capture of Circulating Tumor Cells: Next-Generation Devices and Materials. Angewandte Chemie (International ed.) 55, 1252-1265.

[50] Huang, X. 2017 Gold Nanoparticle Based Platforms for Circulating Cancer Marker Detection. Nanotheranostics (Sydney, NSW) 1, 80-102.

[51] Nies, C. 2019 A Microcavity Array-Based 4D Cell Culture Platform. Bioengineering (Basel) 6.

[52] Asghar, W. 2015 Engineering cancer microenvironments for in vitro 3-D tumor models. Materials today (Kidlington, England) 18, 539-553.

[53] Gu, L. 2016 Biomaterials and emerging anticancer therapeutics: engineering the microenvironment. Nature reviews. Cancer 16, 56-66.

[54] Verjans, E.-T. 2018 Three-dimensional cell culture models for anticancer drug screening: Worth the effort? Journal of cellular physiology 233, 2993-3003.

[55] Ferreira, M.M. 2016 Circulating tumor cell technologies. Molecular oncology 10, 374-394.

[56] Riethdorf, S., Fritsche, H., Müller, V., Rau, T., Schindlbeck, C., Rack, B., Janni, W., Coith, C., Beck, K. \& Jänicke, F. 2007 Detection of circulating tumor cells in peripheral blood of patients with metastatic breast cancer: a validation study of the CellSearch system. Clinical cancer research 13, 920-928.

[57] Umer, M., Vaidyanathan, R., Nguyen, N.-T. \& Shiddiky, M.J. 2018 Circulating tumor microemboli: Progress in molecular understanding and enrichment technologies. Biotechnology advances.

[58] Allan, A.L. \& Keeney, M. 2010 Circulating tumor cell analysis: technical and statistical considerations for application to the clinic. Journal of oncology 2010.

[59] Tibbe, A.G., Miller, M.C. \& Terstappen, L.W. 2007 Statistical considerations for enumeration of circulating tumor cells. Cytometry Part A: the journal of the International Society for Analytical Cytology 71, 154-162.

[60] Regmi, S. 2017 High Shear Stresses under Exercise Condition Destroy Circulating Tumor Cells in a Microfluidic System. Scientific reports 7.

[61] Svensson, C.M., Krusekopf, S., Lücke, J. \& Thilo Figge, M. 2014 Automated detection of circulating tumor cells with naive Bayesian classifiers. Cytometry Part A 85, 501-511.

[62] Huang, G. 2017 Functional and Biomimetic Materials for Engineering of the Three-Dimensional Cell Microenvironment. Chemical reviews 117, 12764-12850.

[63] Jin, C., McFaul, S.M., Duffy, S.P., Deng, X., Tavassoli, P., Black, P.C. \& Ma, H. 2014 Technologies for label-free separation of circulating tumor cells: from historical foundations to recent developments. Lab on a Chip 14, 32-44.

[64] Low, W.S., Abas, W. \& Bakar, W.A. 2015 Benchtop technologies for circulating tumor cells separation based on biophysical properties. BioMed research international 2015.

[65] Sioss, J.A., Bhiladvala, R.B., Pan, W., Li, M., Patrick, S., Xin, P., Dean, S.L., Keating, C.D., Mayer, T.S. \& Clawson, G.A. 2012 Nanoresonator chip-based RNA sensor strategy for detection of circulating tumor cells: response using PCA3 as a prostate cancer marker. Nanomedicine: Nanotechnology, Biology and Medicine 8, 1017-1025. 
[66] Wang, X., Qian, X., Beitler, J.J., Chen, G.Z., Khuri, F.R., Lewis, M.M., Shin, H.J.C., Nie, S. \& Shin, D.M. 2011 Detection of circulating tumor cells in human peripheral blood using surface-enhanced Raman scattering nanoparticles. Cancer research, canres. 3069.2010.

[67] Alix-Panabières, C. 2012 EPISPOT assay: detection of viable DTCs/CTCs in solid tumor patients. In Minimal Residual Disease and Circulating Tumor Cells in Breast Cancer (pp. 69-76, Springer.

[68] Barradas, A. \& Terstappen, L. 2013 Towards the biological understanding of CTC: capture technologies, definitions and potential to create metastasis. Cancers 5, 1619-1642.

[69] Lang, J.M., Casavant, B.P. \& Beebe, D.J. 2012 Circulating tumor cells: getting more from less. Science translational medicine 4, 141ps113-141ps113.

[70] Parkinson, D.R., Dracopoli, N., Petty, B.G., Compton, C., Cristofanilli, M., Deisseroth, A., Hayes, D.F., Kapke, G., Kumar, P. \& Lee, J.S. 2012 Considerations in the development of circulating tumor cell technology for clinical use. Journal of translational medicine 10, 138.

[71] Sharma, S., Zhuang, R., Long, M., Pavlovic, M., Kang, Y., Ilyas, A. \& Asghar, W. 2018 Circulating tumor cell isolation, culture, and downstream molecular analysis. Biotechnology advances.

[72] Tsao, S.C.-H., Wang, J., Wang, Y., Behren, A., Cebon, J. \& Trau, M. 2018 Characterising the phenotypic evolution of circulating tumour cells during treatment. Nature communications $\mathbf{9}, 1482$.

[73] Tang, F. 2019 Fabrication of perforated polyethylene microfiltration membranes for circulating tumor cells separation by thermal nanoimprint method. Applied physics. A, Materials science \& processing 125.

[74] Qin, X. 2015 Size and deformability based separation of circulating tumor cells from castrate resistant prostate cancer patients using resettable cell traps. Lab on a chip 15, 2278-2286.

[75] Kitz, J., Lowes, L., Goodale, D. \& Allan, A. 2018 Circulating tumor cell analysis in preclinical mouse models of metastasis. Diagnostics 8, 30.

[76] Adams, D.L. 2015 Cytometric characterization of circulating tumor cells captured by microfiltration and their correlation to the CellSearch $\left.{ }^{\circledR}\right)$ CTC test. Cytometry. Part A 87, 137-144.

[77] Broncy, L. 2018 Single-cell genetic analysis validates cytopathological identification of circulating cancer cells in patients with clear cell renal cell carcinoma. Oncotarget $\mathbf{9}$.

[78] Sarioglu, A.F., Aceto, N., Kojic, N., Donaldson, M.C., Zeinali, M., Hamza, B., Engstrom, A., Zhu, H., Sundaresan, T.K. \& Miyamoto, D.T. 2015 A microfluidic device for label-free, physical capture of circulating tumor cell clusters. Nature methods 12, 685.

[79] Harouaka, R.A. 2014 Flexible micro spring array device for high-throughput enrichment of viable circulating tumor cells. Clinical chemistry (Baltimore, Md.) 60, 323-333.

[80] Dolfus, C., Piton, N., Toure, E. \& Sabourin, J.-C. 2015 Circulating tumor cell isolation: the assets of filtration methods with polycarbonate track-etched filters. Chinese Journal of Cancer Research 27, 479. [81] Gascoyne, P.R. 2012 Isolation and characterization of cells by dielectrophoretic field-flow fractionation. In Field-Flow Fractionation in Biopolymer Analysis (pp. 255-275, Springer.

[82] Gascoyne, P.R., Shim, S., Noshari, J., Becker, F.F. \& Stemke-Hale, K. 2013 Correlations between the dielectric properties and exterior morphology of cells revealed by dielectrophoretic field-flow fractionation. Electrophoresis 34, 1042-1050.

[83] Gascoyne, P.R. \& Vykoukal, J.V. 2004 Dielectrophoresis-based sample handling in general-purpose programmable diagnostic instruments. Proceedings of the IEEE 92, 22-42.

[84] Strimbu, K. \& Tavel, J.A. 2010 What are biomarkers? Current Opinion in HIV and AIDS 5, 463.

[85] Osta, W.A. 2004 EpCAM is overexpressed in breast cancer and is a potential target for breast cancer gene therapy. Cancer research (Chicago, III.) 64, 5818-5824.

[86] Pantel, K., Denève, E., Nocca, D., Coffy, A., Vendrell, J.-P., Maudelonde, T., Riethdorf, S. \& AlixPanabières, C. 2012 Circulating epithelial cells in patients with benign colon diseases. Clinical chemistry 58, 936-940.

[87] Khoja, L., Backen, A., Sloane, R., Menasce, L., Ryder, D., Krebs, M., Board, R., Clack, G., Hughes, A. \& Blackhall, F. 2012 A pilot study to explore circulating tumour cells in pancreatic cancer as a novel biomarker. British journal of cancer 106, 508. 
[88] Liu, Z. 2011 Negative enrichment by immunomagnetic nanobeads for unbiased characterization of circulating tumor cells from peripheral blood of cancer patients. Journal of translational medicine 9.

[89] Pantel, K., Alix-Panabières, C. \& Riethdorf, S. 2009 Cancer micrometastases. Nature reviews Clinical oncology 6, 339.

[90] Talasaz, A.H., Powell, A.A., Huber, D.E., Berbee, J.G., Roh, K.-H., Yu, W., Xiao, W., Davis, M.M., Pease, R.F. \& Mindrinos, M.N. 2009 Isolating highly enriched populations of circulating epithelial cells and other rare cells from blood using a magnetic sweeper device. Proceedings of the National Academy of Sciences 106, 3970-3975.

[91] Saucedo-Zeni, N., Mewes, S., Niestroj, R., Gasiorowski, L., Murawa, D., Nowaczyk, P., Tomasi, T., Weber, E., Dworacki, G. \& Morgenthaler, N.G. 2012 A novel method for the in vivo isolation of circulating tumor cells from peripheral blood of cancer patients using a functionalized and structured medical wire. International journal of oncology 41, 1241-1250.

[92] Ozkumur, E., Shah, A.M., Ciciliano, J.C., Emmink, B.L., Miyamoto, D.T., Brachtel, E., Yu, M., Chen, P.-i., Morgan, B. \& Trautwein, J. 2013 Inertial focusing for tumor antigen-dependent andindependent sorting of rare circulating tumor cells. Science translational medicine 5, 179ra147179 ra147.

[93] Nagrath, S., Sequist, L.V., Maheswaran, S., Bell, D.W., Irimia, D., Ulkus, L., Smith, M.R., Kwak, E.L., Digumarthy, S. \& Muzikansky, A. 2007 Isolation of rare circulating tumour cells in cancer patients by microchip technology. Nature 450, 1235-1239.

[94] Stott, S.L., Hsu, C.-H., Tsukrov, D.I., Yu, M., Miyamoto, D.T., Waltman, B.A., Rothenberg, S.M., Shah, A.M., Smas, M.E. \& Korir, G.K. 2010 Isolation of circulating tumor cells using a microvortexgenerating herringbone-chip. Proceedings of the National Academy of Sciences 107, 18392-18397.

[95] Andreopoulou, E., Yang, L.Y., Rangel, K., Reuben, J., Hsu, L., Krishnamurthy, S., Valero, V., Fritsche, H. \& Cristofanilli, M. 2012 Comparison of assay methods for detection of circulating tumor cells in metastatic breast cancer: AdnaGen AdnaTest BreastCancer Select/Detect ${ }^{\mathrm{TM}}$ versus Veridex CellSearch ${ }^{\mathrm{TM}}$ system. International journal of cancer 130, 1590-1597.

[96] Harb, W., Fan, A., Tran, T., Danila, D.C., Keys, D., Schwartz, M. \& Ionescu-Zanetti, C. 2013 Mutational analysis of circulating tumor cells using a novel microfluidic collection device and qPCR assay. Translational oncology 6, 528-IN521.

[97] Chen, H., Zhang, W., Zhu, G., Xie, J. \& Chen, X. 2017 Rethinking cancer nanotheranostics. Nature Reviews Materials 2, 17024.

[98] Chinen, A.B., Guan, C.M., Ferrer, J.R., Barnaby, S.N., Merkel, T.J. \& Mirkin, C.A. 2015 Nanoparticle probes for the detection of cancer biomarkers, cells, and tissues by fluorescence. Chemical reviews 115, 10530-10574.

[99] Fan, Z., Senapati, D., Singh, A.K. \& Ray, P.C. 2012 Theranostic magnetic core-plasmonic shell star shape nanoparticle for the isolation of targeted rare tumor cells from whole blood, fluorescence imaging, and photothermal destruction of cancer. Molecular pharmaceutics 10, 857-866.

[100] Fan, Z., Shelton, M., Singh, A.K., Senapati, D., Khan, S.A. \& Ray, P.C. 2012 Multifunctional plasmonic shell-magnetic core nanoparticles for targeted diagnostics, isolation, and photothermal destruction of tumor cells. ACS nano 6, 1065-1073.

[101] Akpe, V., Shiddiky, M.J.A., Kim, T.H., Brown, C.L., Yamauchi, Y. \& Cock, I.E. 2020 Cancer biomarker profiling using nanozyme containing iron oxide loaded with gold particles. Journal of The Royal Society Interface 17, 20200180. (doi:doi:10.1098/rsif.2020.0180).

[102] Attard, G. \& de Bono, J.S. 2011 Translating scientific advancement into clinical benefit for castration-resistant prostate cancer patients. Clinical Cancer Research 17, 3867-3875.

[103] Attard, G., Richards, J. \& de Bono, J.S. 2011 New strategies in metastatic prostate cancer: targeting the androgen receptor signaling pathway. Clinical cancer research 17, 1649-1657.

[104] Cima, I., Wen Yee, C., Iliescu, F.S., Min Phyo, W., Hon Lim, K., Iliescu, C. \& Han Tan, M. 2013 Label-free isolation of circulating tumor cells in microfluidic devices: Current research and perspectives. Biomicrofluidics 7, 011810. 
[105] Myung, J. \& Hong, S. 2015 Microfluidic devices to enrich and isolate circulating tumor cells. Lab on a Chip 15, 4500-4511.

[106] Zheng, S., Lin, H., Liu, J.-Q., Balic, M., Datar, R., Cote, R.J. \& Tai, Y.-C. 2007 Membrane microfilter device for selective capture, electrolysis and genomic analysis of human circulating tumor cells. Journal of chromatography A 1162, 154-161.

[107] Nguyen, N.-T. \& Wu, Z. 2004 Micromixers-a review. Journal of micromechanics and microengineering 15, R1.

[108] Guo, J., Pui, T.S., Ban, Y.-L., Rahman, A.R.A. \& Kang, Y. 2013 Electrokinetic analysis of cell translocation in low-cost microfluidic cytometry for tumor cell detection and enumeration. IEEE Transactions on Biomedical Engineering 60, 3269-3275.

[109] Iliescu, F.S., Vrtačnik, D., Neuzil, P. \& Iliescu, C. 2019 Microfluidic technology for clinical applications of exosomes. Micromachines 10, 392.

[110] Moon, H.-S., Kwon, K., Kim, S.-I., Han, H., Sohn, J., Lee, S. \& Jung, H.-I. 2011 Continuous separation of breast cancer cells from blood samples using multi-orifice flow fractionation (MOFF) and dielectrophoresis (DEP). Lab on a Chip 11, 1118-1125.

[111] Khan, M., Mao, S., Li, W. \& Lin, J.-M. 2018 Microfluidic devices in the fast-growing domain of single-cell analysis. Chemistry-A European Journal.

[112] Turk-MacLeod, R., Henson, A., Rodriguez-Garcia, M., Gibson, G.M., Camarasa, G.A., Caramelli, D., Padgett, M.J. \& Cronin, L. 2018 Approach to classify, separate, and enrich objects in groups using ensemble sorting. Proceedings of the National Academy of Sciences 115, 5681-5685.

[113] Zhao, M., Schiro, P.G. \& Chiu, D.T. 2016 Ensemble-decision Aliquot Ranking (eDAR) for CTC Isolation and Analysis. Circulating Tumor Cells: Isolation and Analysis, 51-84.

[114] Segre, G. \& Silberberg, A. 1962 Behaviour of macroscopic rigid spheres in Poiseuille flow Part 2. Experimental results and interpretation. Journal of fluid mechanics 14, 136-157.

[115] Warkiani, M.E. 2016 Ultra-fast, label-free isolation of circulating tumor cells from blood using spiral microfluidics. Nature protocols 11, 134-148.

[116] Bhagat, A.A.S. 2008 Continuous particle separation in spiral microchannels using dean flows and differential migration. Lab on a chip 8.

[117] Di Carlo, D. 2009 Inertial microfluidics. Lab on a Chip 9, 3038-3046.

[118] Aref, H., Blake, J.R., Budišić, M., Cardoso, S.S., Cartwright, J.H., Clercx, H.J., El Omari, K., Feudel, U., Golestanian, R. \& Gouillart, E. 2017 Frontiers of chaotic advection. Reviews of Modern Physics 89, 025007.

[119] Howell, J.P.B. 2004 Design and evaluation of a Dean vortex-based micromixer. Lab on a chip 4.

[120] Wang, X., Zandi, M., Ho, C.-C., Kaval, N. \& Papautsky, I. 2015 Single stream inertial focusing in a straight microchannel. Lab on a Chip 15, 1812-1821.

[121] Zhou, J., Kulasinghe, A., Bogseth, A., O'Byrne, K., Punyadeera, C. \& Papautsky, I. 2019 Isolation of circulating tumor cells in non-small-cell-lung-cancer patients using a multi-flow microfluidic channel. Microsystems \& nanoengineering 5, 1-12.

[122] Zhou, J. \& Papautsky, I. 2013 Fundamentals of inertial focusing in microchannels. Lab on a Chip 13, 1121-1132.

[123] Tu, C., Zhou, J., Liang, Y., Huang, B., Fang, Y., Liang, X. \& Ye, X. 2017 A flexible cell concentrator using inertial focusing. Biomedical microdevices 19, 83.

[124] Sollier, E., Go, D.E., Che, J., Gossett, D.R., O'Byrne, S., Weaver, W.M., Kummer, N., Rettig, M., Goldman, J. \& Nickols, N. 2014 Size-selective collection of circulating tumor cells using Vortex technology. Lab on a Chip 14, 63-77.

[125] Moffatt, H.K. 1964 Viscous and resistive eddies near a sharp corner. Journal of Fluid Mechanics 18, 1-18.

[126] Liu, Y., Wang, W., Wu, W., Yang, F. \& Li, H. 2015 Filtration membrane with ultra-high porosity and pore size controllability fabricated by parylene $\mathrm{c}$ molding technique for targeted cell separation from bronchoalveolar lavage fluid (BALF). In 2015 Transducers-2015 18th International Conference on Solid-State Sensors, Actuators and Microsystems (TRANSDUCERS) (pp. 1767-1769, IEEE. 
[127] Liu, Y. 2019 A high-throughput liquid biopsy for rapid rare cell separation from large-volume samples. Lab on a chip 19, 68-78.

[128] Yeo, J.C. 2018 Label-free extraction of extracellular vesicles using centrifugal microfluidics. Biomicrofluidics 12.

[129] Gjorevski. 2016 Designer matrices for intestinal stem cell and organoid culture. ON nature 539. [130] Raposo, G. \& Stoorvogel, W. 2013 Extracellular vesicles: exosomes, microvesicles, and friends. J Cell Biol 200, 373-383.

[131] Firouzi, M., Nguyen, A.V. \& Hashemabadi, S.H. 2011 The effect of microhydrodynamics on bubble-particle collision interaction. Minerals Engineering 24, 973-986.

[132] Onidani, K., Shoji, H., Kakizaki, T., Yoshimoto, S., Okaya, S., Miura, N., Sekikawa, S., Furuta, K., Lim, C.T. \& Shibahara, T. 2019 Monitoring of cancer patients via next-generation sequencing of patient-derived circulating tumor cells and tumor DNA. Cancer science 110, 2590.

[133] Minciacchi, V., Zijlstra, A., Rubin, M.A. \& Di Vizio, D. 2017 Extracellular vesicles for liquid biopsy in prostate cancer: where are we and where are we headed? Prostate cancer and prostatic diseases 20, 251-258.

[134] Woo, H.-K., Park, J., Ku, J.Y., Lee, C.H., Sunkara, V., Ha, H.K. \& Cho, Y.-K. 2019 Urine-based liquid biopsy: non-invasive and sensitive AR-V7 detection in urinary EVs from patients with prostate cancer. Lab on a Chip 19, 87-97.

[135] Woo, H.-K., Sunkara, V., Park, J., Kim, T.-H., Han, J.-R., Kim, C.-J., Choi, H.-I., Kim, Y.-K. \& Cho, Y.K. 2017 Exodisc for rapid, size-selective, and efficient isolation and analysis of nanoscale extracellular vesicles from biological samples. Acs Nano 11, 1360-1370.

[136] Anderson, C. 2020 Comprehensive Approach: Epic Sciences has retooled its management team and is combining CTC and ctDNA technologies in its pursuit of comprehensive cancer profiling. Clinical OMICs 7, 24-26.

[137] Werner, S.L., Graf, R.P., Landers, M., Valenta, D.T., Schroeder, M., Greene, S.B., Bales, N., Dittamore, R. \& Marrinucci, D. 2015 Analytical validation and capabilities of the epic CTC platform: enrichment-free circulating tumour cell detection and characterization. Journal of Circulating Biomarkers 4, 3.

[138] Das, P. 2016 Recent advances on developing 3rd generation enzyme electrode for biosensor applications. Biosensors \& bioelectronics 79, 386-397.

[139] Gill, A.A., Singh, S., Thapliyal, N. \& Karpoormath, R. 2019 Nanomaterial-based optical and electrochemical techniques for detection of methicillin-resistant Staphylococcus aureus: a review. Microchimica Acta 186, 114.

[140] Grieshaber, D., MacKenzie, R., Voeroes, J. \& Reimhult, E. 2008 Electrochemical biosensorssensor principles and architectures. Sensors 8, 1400-1458.

[141] Hatta, A. 1985 Infrared absorption study of adsorbed species at metal/water interface by use of the Kretschmann configuration. Surface science 158, 616-623.

[142] Suzuki, Y. 1988 Mechanism of absorption enhancement in infrared ATR spectra observed in the Kretschmann configuration. Applied surface science 33-34, 875-881.

[143] Liedberg, B. 1993 Principles of biosensing with an extended coupling matrix and surface plasmon resonance. Sensors and actuators. B, Chemical 11, 63-72.

[144] Le Ru, E. \& Etchegoin, P. 2008 Principles of Surface-Enhanced Raman Spectroscopy: and related plasmonic effects, Elsevier.

[145] Wang, S.-S., Zhao, X.-P., Liu, F.-F., Younis, M.R., Xia, X.-H. \& Wang, C. 2019 Direct PlasmonEnhanced Electrochemistry Enables Ultrasensitive and Label-Free Detection of Circulating Tumor Cells in Blood. Analytical chemistry.

[146] Reokrungruang, P. 2019 A simple paper-based surface enhanced Raman scattering (SERS) platform and magnetic separation for cancer screening. Sensors and actuators. B, Chemical 285, 462469. 
[147] Kim, W., Kim, Y.-H., Park, H.-K. \& Choi, S. 2015 Facile fabrication of a silver nanoparticle immersed, surface-enhanced Raman scattering imposed paper platform through successive ionic layer absorption and reaction for on-site bioassays. ACS applied materials \& interfaces 7, 27910-27917.

[148] Andree, K.C. 2018 Toward a real liquid biopsy in metastatic breast and prostate cancer: Diagnostic LeukApheresis increases CTC yields in a European prospective multicenter study (CTCTrap). International journal of cancer 143, 2584-2591.

[149] Balkwill, F. \& Mantovani, A. 2001 Inflammation and cancer: back to Virchow? The lancet 357, 539-545.

[150] Barnes, J.M., Nauseef, J.T. \& Henry, M.D. 2012 Resistance to fluid shear stress is a conserved biophysical property of malignant cells. PloS one 7, e50973.

[151] Chaffer, C.L. \& Weinberg, R.A. 2011 A perspective on cancer cell metastasis. Science 331, 15591564.

[152] Chambers, A.F., Groom, A.C. \& MacDonald, I.C. 2002 Metastasis: dissemination and growth of cancer cells in metastatic sites. Nature Reviews Cancer 2, 563.

[153] Chen, M. \& Geng, J.-G. 2006 P-selectin mediates adhesion of leukocytes, platelets, and cancer cells in inflammation, thrombosis, and cancer growth and metastasis. Archivum immunologiae et therapiae experimentalis 54, 75-84.

[154] Coultas, L., Chawengsaksophak, K. \& Rossant, J. 2005 Endothelial cells and VEGF in vascular development. Nature 438, 937.

[155] DeVita Jr, V.T. \& Rosenberg, S.A. 2012 Two hundred years of cancer research. New England Journal of Medicine 366, 2207-2214.

[156] Ewing, J. 1928 Neoplastic diseases. A treatise on tumors. The American Journal of the Medical Sciences 176, 278.

[157] Geng, J.-G., Chen, M. \& Chou, K.-C. 2004 P-selectin cell adhesion molecule in inflammation, thrombosis, cancer growth and metastasis. Current medicinal chemistry 11, 2153-2160.

[158] Gupta, G.P. \& Massagué, J. 2006 Cancer metastasis: building a framework. Cell 127, 679-695.

[159] Kaiser, J. 2010 Cancer's circulation problem. (American Association for the Advancement of Science.

[160] Kardinal, C.G. \& Yarbro, J.W. 1979 A conceptual history of cancer. In Seminars in Oncology (pp. 396-408, Elsevier.

[161] Mathot, L. \& Stenninger, J. 2012 Behavior of seeds and soil in the mechanism of metastasis: a deeper understanding. Cancer science 103, 626-631.

[162] Minn, A.J., Kang, Y., Serganova, I., Gupta, G.P., Giri, D.D., Doubrovin, M., Ponomarev, V., Gerald, W.L., Blasberg, R. \& Massagué, J. 2005 Distinct organ-specific metastatic potential of individual breast cancer cells and primary tumors. The Journal of clinical investigation 115, 44-55.

[163] Morgan-Parkes, J.H. 1995 Metastases: mechanisms, pathways, and cascades. AJR. American journal of roentgenology 164, 1075-1082.

[164] Nguyen, D.X., Bos, P.D. \& Massagué, J. 2009 Metastasis: from dissemination to organ-specific colonization. Nature Reviews Cancer 9, 274.

[165] Paget, S. 1889 The distribution of secondary growths in cancer of the breast. The Lancet 133, 571-573.

[166] Poste, G. \& Paruch, L. 1989 Stephen Paget, MD, FRCS,(1855-1926) A retrospective. Cancer and metastasis reviews 8, i-97.

[167] Ribatti, D., Mangialardi, G. \& Vacca, A. 2006 Stephen Paget and the 'seed and soil'theory of metastatic dissemination. Clinical and experimental medicine 6, 145-149.

[168] Tomatis, L. 1993 Cell proliferation and carcinogenesis: a brief history and current view based on an IARC workshop report. International Agency for Research on Cancer. Environmental health perspectives 101, 149.

[169] Watanabe, S. 1954 The metastasizability of tumor cells. Cancer 7, 215-223.

[170] Suzuki, K. \& Matsubara, H. 2011 Recent advances in p53 research and cancer treatment. BioMed Research International 2011. 
[171] Crusz, S.M. \& Balkwill, F.R. 2015 Inflammation and cancer: advances and new agents. Nature reviews Clinical oncology 12, 584.

[172] Nasir, A. 2019 Angiogenic Signaling Pathways and Anti-angiogenic Therapies in Human Cancer. In Predictive Biomarkers in Oncology (pp. 243-262, Springer.

[173] Zhang, Y., Brewer, A.L., Nelson, J.T., Smith, P.T., Shirachi, D.Y. \& Quock, R.M. 2019 Hyperbaric oxygen produces a nitric oxide synthase-regulated anti-allodynic effect in rats with paclitaxel-induced neuropathic pain. Brain research.

[174] Liu, J., Wang, L., Wang, Z. \& Liu, J.-P. 2019 Roles of Telomere Biology in Cell Senescence, Replicative and Chronological Ageing. Cells 8, 54.

[175] Butti, R., Gunasekaran, V.P., Kumar, T.V., Banerjee, P. \& Kundu, G.C. 2019 Breast cancer stem cells: Biology and therapeutic implications. The international journal of biochemistry \& cell biology 107, 38-52.

[176] Ahmadbeigi, N. 2012 The aggregate nature of human mesenchymal stromal cells in native bone marrow. Cytotherapy (Oxford, England) 14, 917-924.

[177] Huang, J. 2015 ELISpot and ELISA analyses of human IL-21-secreting cells: Impact of blocking IL21 interaction with cellular receptors. Journal of immunological methods 417, 60-66.

[178] Paris, P.L., Kobayashi, Y., Zhao, Q., Zeng, W., Sridharan, S., Fan, T., Adler, H.L., Yera, E.R., Zarrabi, M. \& Zucker, S. 2009 Functional phenotyping and genotyping of circulating tumor cells from patients with castration resistant prostate cancer. Cancer letters 277, 164-173.

[179] Tulley, S. 2016 Breast Cancer Vita-Assay ${ }^{\mathrm{TM}}$ Method of Enrichment and Identification of Circulating Cancer Cells/Circulating Tumor Cells (CTCS). 107-119.

[180] Issadore, D. $2013 \mu \mathrm{Hall}$ Chip for Sensitive Detection of Bacteria. Advanced healthcare materials 2, 1224-1228.

[181] Autebert, J. 2015 High purity microfluidic sorting and analysis of circulating tumor cells: towards routine mutation detection. Lab on a chip 15, 2090-2101.

[182] Lee, T.Y. 2017 An integrated microfluidic chip for one-step isolation of circulating tumor cells. Sensors and actuators. B, Chemical 238, 1144-1150.

[183] Hsieh, H.B. 2006 High speed detection of circulating tumor cells. Biosensors \& bioelectronics 21, 1893-1899.

[184] Miller, M.C., Doyle, G.V. \& Terstappen, L.W. 2010 Significance of circulating tumor cells detected by the CellSearch system in patients with metastatic breast colorectal and prostate cancer. Journal of oncology 2010.

[185] Rissin, D.M., Kan, C.W., Campbell, T.G., Howes, S.C., Fournier, D.R., Song, L., Piech, T., Patel, P.P., Chang, L. \& Rivnak, A.J. 2010 Single-molecule enzyme-linked immunosorbent assay detects serum proteins at subfemtomolar concentrations. Nature biotechnology 28, 595.

[186] Hinohara, K. 2019 Intratumoral Heterogeneity: More Than Just Mutations. Trends in cell biology. [187] Scher, H.I. 2017 Phenotypic Heterogeneity of Circulating Tumor Cells Informs Clinical Decisions between AR Signaling Inhibitors and Taxanes in Metastatic Prostate Cancer. Cancer research (Chicago, III.) 77, 5687-5698.

[188] Souslova, E.A. 2017 Applications of genetically encoded photosensitizer miniSOG: from correlative light electron microscopy to immunophotosensitizing. Journal of biophotonics 10, 338-352. [189] Poudineh, M., Sargent, E.H., Pantel, K. \& Kelley, S.O. 2018 Profiling circulating tumour cells and other biomarkers of invasive cancers. Nature Biomedical Engineering 2, 72.

[190] Mittal, R. 2019 Organ-on-chip models: Implications in drug discovery and clinical applications. Journal of cellular physiology 234, 8352-8380.

[191] Azevedo, R., Soares, J., Peixoto, A., Cotton, S., Lima, L., Santos, L.L. \& Ferreira, J.A. 2018 Circulating tumor cells in bladder cancer: Emerging technologies and clinical implications foreseeing precision oncology. In Urologic Oncology: Seminars and Original Investigations (pp. 221-236, Elsevier. [192] Gullo, M.R., Takeuchi, S. \& Paul, O. 2017 Multicellular Biohybrid Materials: Probing the Interplay of Cells of Different Types Precisely Positioned and Constrained on 3D Wireframe-Like Microstructures. Advanced Healthcare Materials 6, 1601053. 
[193] Gullo, R.M., Koeser, J., Ruckli, O., Eigenmann, A. \& Hradetzky, D. 2018 Rapid Prototyping Method for 3D Printed Biomaterial Constructs with Vascular Structures. In 2018 40th Annual International Conference of the IEEE Engineering in Medicine and Biology Society (EMBC) (pp. 5729-5732, IEEE.

[194] Nayak, S., Blumenfeld, N.R., Laksanasopin, T. \& Sia, S.K. 2017 Point-of-care diagnostics: recent developments in a connected age. Analytical chemistry 89, 102-123.

[195] Tsur, E.E. \& Shamir, A. 2018 Computer-aided design of resistance micro-fluidic circuits for 3D printing. Computer-aided design 98, 12-23.

[196] Kuang, X., Roach, D.J., Wu, J., Hamel, C.M., Ding, Z., Wang, T., Dunn, M.L. \& Qi, H.J. 2019 Advances in 4D printing: Materials and applications. Advanced Functional Materials 29, 1805290.

[197] Zhang, Z., Demir, K.G. \& Gu, G.X. 2019 Developments in 4D-printing: a review on current smart materials, technologies, and applications. International Journal of Smart and Nano Materials 10, 205224.

[198] Zhou, Y., Huang, W.M., Kang, S.F., Wu, X.L., Lu, H.B., Fu, J. \& Cui, H. 2015 From 3D to 4D printing: approaches and typical applications. Journal of Mechanical Science and Technology 29, 4281-4288.

[199] Truini, A. 2014 Clinical Applications of Circulating Tumor Cells in Lung Cancer Patients by CellSearch System. Frontiers in oncology 4.

[200] Liu, Y., Li, T., Xu, M., Zhang, W., Xiong, Y., Nie, L., Wang, Q., Li, H. \& Wang, W. 2019 A highthroughput liquid biopsy for rapid rare cell separation from large-volume samples. Lab on a Chip 19, 68-78. 